\title{
The Use and Ease of Access of EBooks in Public Libraries
}

By

\section{Nichola Ross}

Submitted to the School of Information Management,

Victoria University of Wellington

in partial fulfilment of the requirements for the degree of

Master of Information Studies 


\author{
VICTORIA UNIVERSITY OF WELLINGTON \\ School of Information Management
}

\title{
Master of Information Studies
}

\section{IMPORTANT DISCLAIMER}

with respect to a MIS Research Project (INFO 580)

The Use and Ease of Access of EBooks in Public Libraries

(hereafter referred to as 'The MIS Research Project')

being undertaken by

\section{Nichola Ross}

in partial fulfilment of the requirements of the degree of

Master of Information Studies,

School of Information Management, Victoria University of Wellington.

\section{Topic Commencement: Date March 2013}

1. Victoria University of Wellington and its Council, its members, staff, employees, students and agents undertake no duty of care in contract, tort, or otherwise, to users (whether 
direct or indirect) of the MIS Research Project and make no warranties or

representations of any kind whatsoever in relation to any of its contents.

2. The MIS Research Project is only made available on the basis that all users of it, whether direct or indirect, must take appropriate legal or other expert advice in relation to their own circumstances and must rely solely on their own judgement and such legal or other expert advice.

3. Under no circumstances will Victoria University of Wellington and its Council, its members, staff, employees, students or agents be liable in any way whatsoever, whether in contract, tort (including negligence), for breach of any statutory or regulatory duty (to the fullest extent permissible by law), or otherwise, to any user (whether direct or indirect) of the MIS Research Project for any loss or damage whatsoever arising directly or indirectly as a result of the use in any way of the MIS Research Project.

4. Each exclusion in the clauses of this disclaimer and each protection given by it is to be construed as a separate exclusion applying and surviving even if for any reason any of the exclusions or protections are held inapplicable in any circumstance. 


\section{Contents}

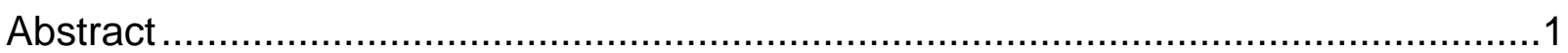

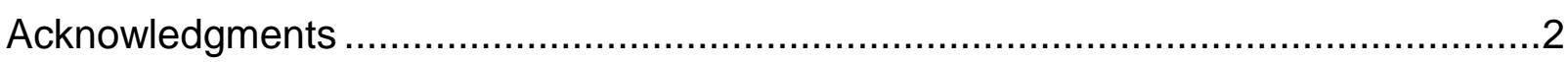

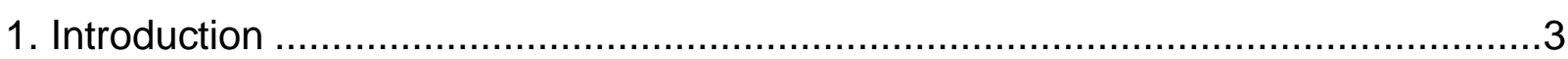

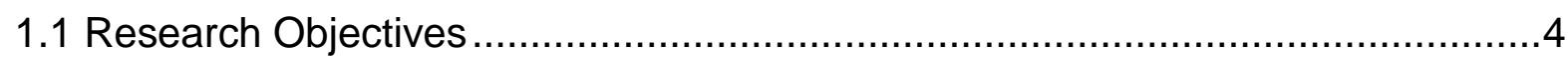

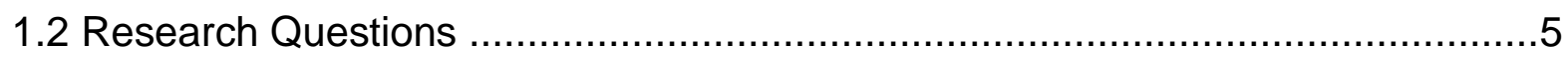

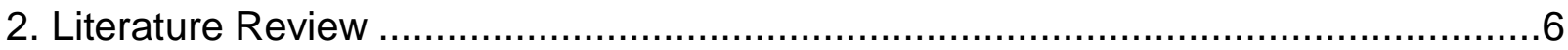

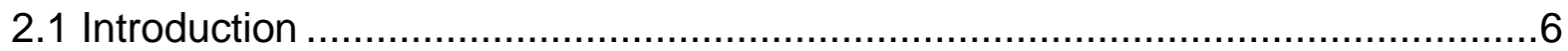

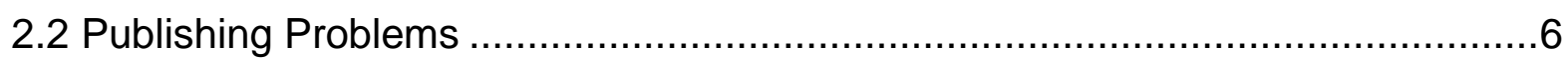

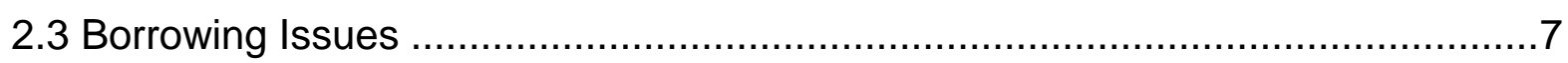

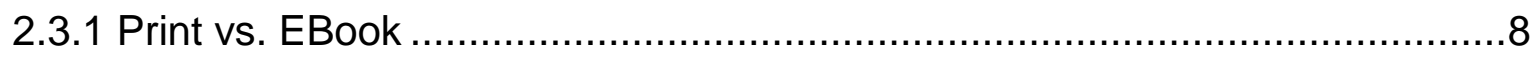

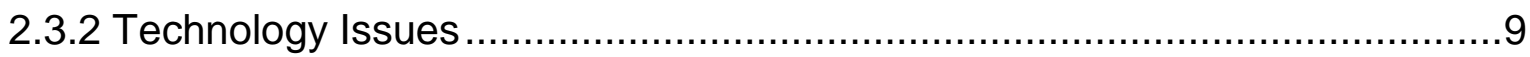

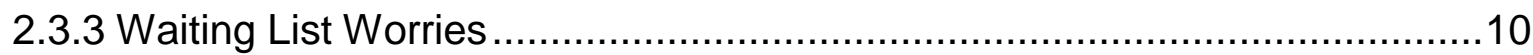

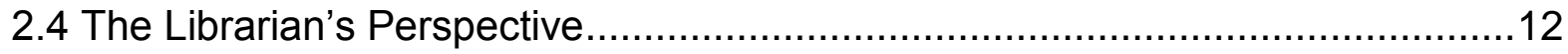

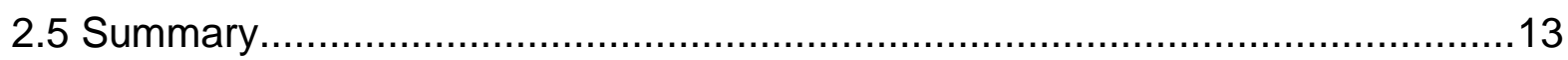

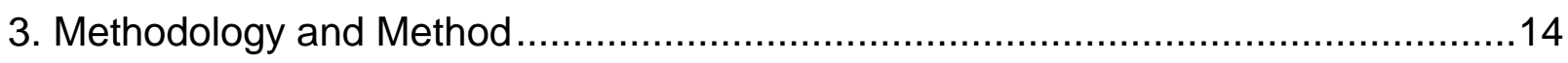

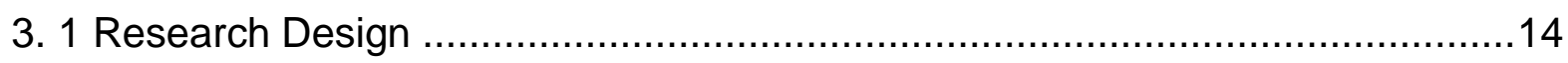

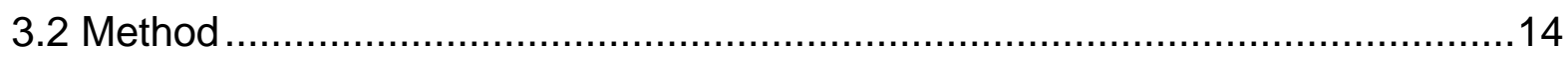

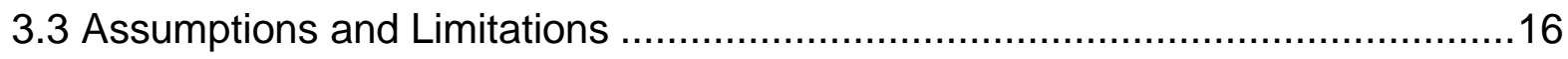

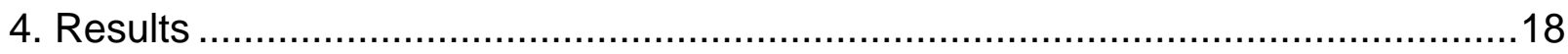

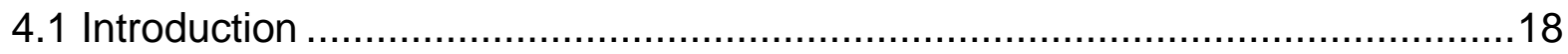

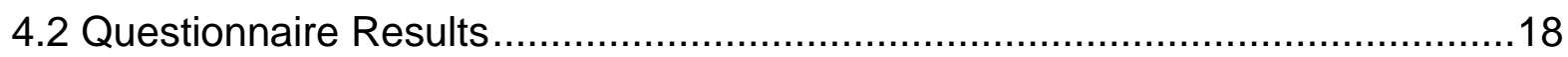

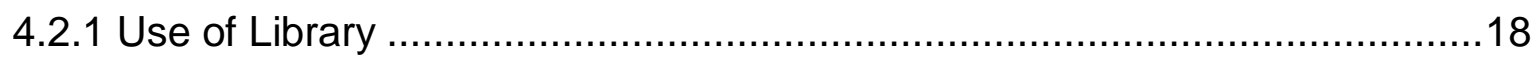

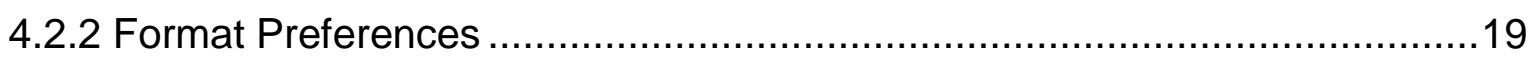

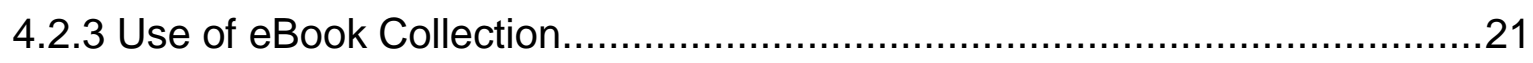

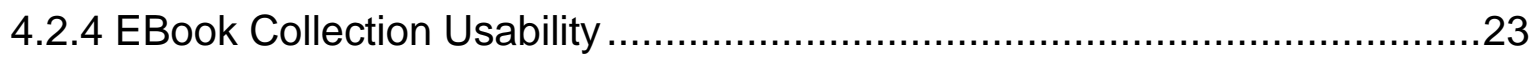

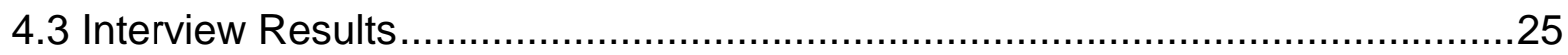

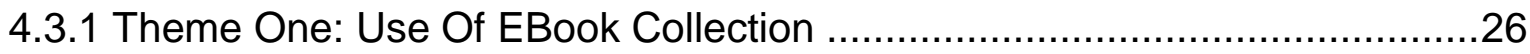

4.3.2 Theme Two: Publishing Problems ………….......................................27

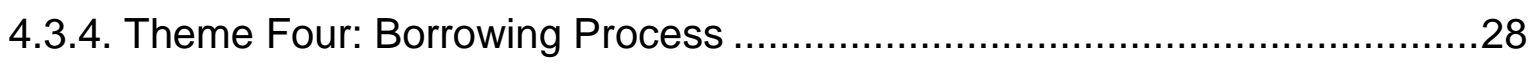

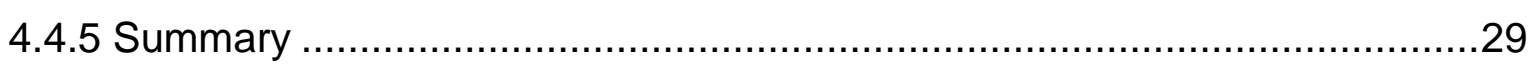

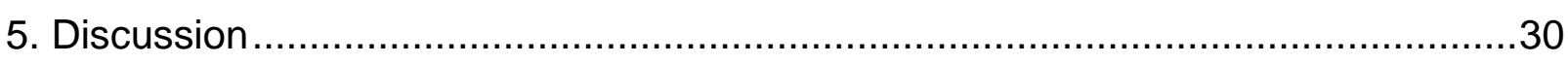

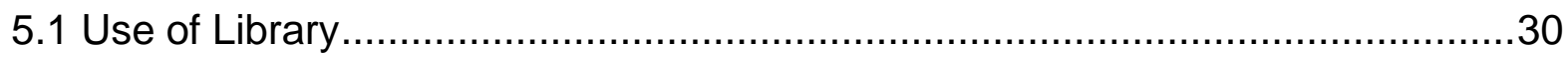

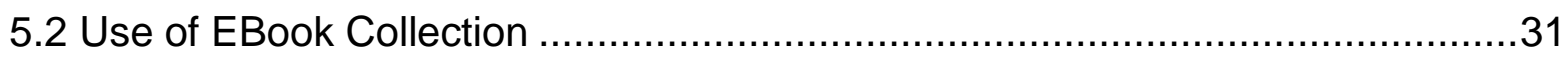




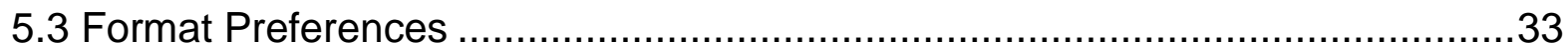

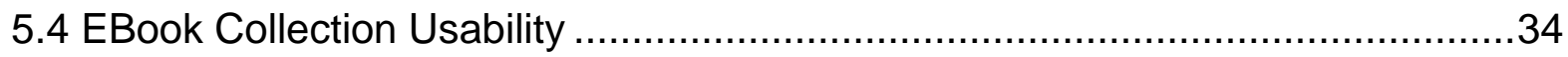

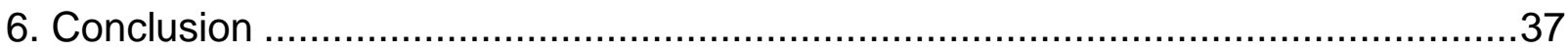

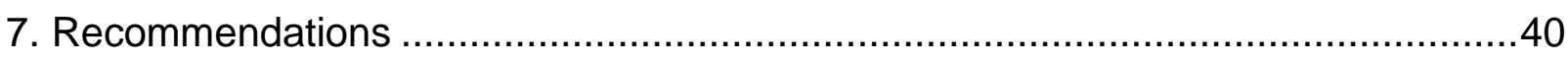

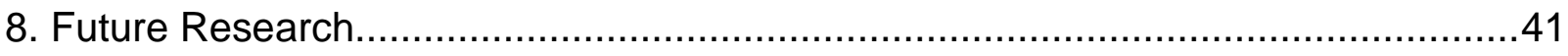

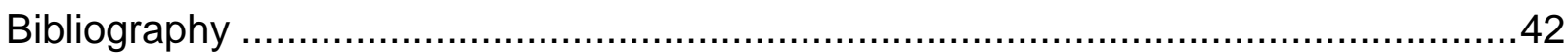

Appendix One: Research Questionnaire Paper Version .......................................45

Appendix Two: Research Questionnaire Online Version........................................48

Appendix Three: Information Sheet For Interview .............................................50

Appendix Four: Permission Form For Interview ..............................................

Appendix Five: Interview Question Guideline Sheet.............................................52 


\section{Abstract}

Research Problem: The purpose of this research project is to examine how patrons are using the eBook collection at a New Zealand public library. Specifically the research examines the relationship between print and eBooks and how this relationship affects borrowing habits. It also explores how the eBook borrowing process for affects usage of the collection. There is little information on this topic from a library patron perspective, and even less research conducted in a New Zealand context.

Methodology: Both qualitative and quantitative methods were used in this research. Self-completion questionnaires with a combination of quantitative and qualitative questions were offered to members of Christchurch City Libraries. A semi-structured interview was also conducted with two library staff members.

Results: It can be observed that print is still the most borrowed and the favoured format. There are a number of reasons for this but the most prominent was that eBooks cannot offer the same sensations and reading experience that a print book gives. Most users were happy with using only print books though the ones that were open to trying eBooks were unable to do so as they did not own eReaders. The incompatibility of Amazon Kindles was also a reason some patrons were borrowing print books as they were unable to get the titles they wanted for their eReaders. The small size of the eBook collection was a deterrent for some users but the library is aware of this and is working towards building a larger collection with a wider selection.

Key Words: EBooks, Public Libraries, Borrow/Borrowing, New Zealand 


\section{Acknowledgments}

First I would like to thank my supervisor Anne Goulding for her support and guidance during this project.

Thanks to Anne Anderson for being my liaison with the library and helping me organise the locations and interviewees for this project.

I would also like to thank Christchurch City Libraries for allowing me to conduct my research at their branches. A particular thanks to the staff at Central Peterborough and South libraries who made me welcome and offered advice while I collected my data.

Finally thanks to all those who completed the questionnaire and to the interviewees.

Nichola Ross

2013 


\section{Introduction}

The use of eBooks has increased dramatically over the last few years (Zickuhr et al, 2012). This has been driven by the development of eReaders and other digital reading devices, which have made access to eBooks easier for the general public (Richardson and Mahmood, 2011). As a result eBooks have been brought to the attention of the public creating a rise in demand. Public libraries have been slower to add eBooks to their catalogue than academic libraries (Ashcroft, 2011). There are a number of reasons for this, including publishing and technological issues, which are discussed in the literature examined below. This research project aims to discover how patrons are using eBooks in a New Zealand public library. Specifically it will examine the relationship between print and eBooks, along with the current eBook borrowing process. The aim is to discover whether patrons are satisfied with the ease of the borrowing process, or whether it could be improved.

Current research on eBooks is largely centred on libraries, their staff and their responses to eBook implementation (Kelsey, 2012; Moyer and Thiele, 2011). Library patrons are an important group which are being largely ignored. Public libraries will need to introduce eBooks as the demand for them in their community increases. As more people become aware of eBooks, and as the price of the technology falls, demand increases (Duncan, 2011). The current research identifies ease of access as one of the main issues for eBook users (Ashcroft 2011). The vast majority of the research on this topic has been done overseas, as is evident in the literature reviews by Moyer and Thiele (2011) and Linda Ashcroft (2011). However LIANZA has recently released a paper of their findings on e-content and e-lending in New Zealand (2013). This project aims to provide the public libraries of New Zealand an indication of how communities have responded to eBooks in public libraries. Understanding the public's point of view will help libraries make a decision on eBooks which is right for their community. This research project will examine this issue in a New Zealand context to discover if the same problems that exist overseas are prevalent in New Zealand. 


\subsection{Research Objectives}

The research project aims to examine how patrons are using eBooks in a New Zealand public library. This is an important topic to explore for a number of reasons, the first being that very little research has been conducted in this area. Research has been undertaken recently in the UK and USA on eBook use in public libraries (Poulson, 2012) and LIANZA has released a paper on e-lending in New Zealand (LIANZA, 2013). A greater number of studies have been carried out in academic libraries (Ashcroft, 2011). This topic is current, studies show that eBook collection development is occurring in public libraries around the world, and the development of digital resources is a high priority in public libraries (see: CILIP Policy Department, 2012c; Zickuhr et al, 2012; OCLC, 2012). While eBooks have been around for a number of years it is only in the last few years that public libraries have begun to make them available, this is due to a rise in public demand driven by the advent of new digital eReading devices (Richardson and Mahmood, 2011). The situation in New Zealand is different; the services available differ as do the range of devices compatible with eBook lending (Overdrive n.d.; LIANZA, 2013) and while some inferences can be made from previous research it is important that studies be carried out in New Zealand to gain accurate data in its specific context.

Secondly, EBooks are a relatively new service so it is important for libraries to understand how they are being used and whether users are happy with the current borrowing process. Borrowing an eBook should be just as simple as borrowing a print book; since many people do not have great technological skills it is vital that libraries make the process as simple as possible. An important step towards this is getting feedback from the current users on the ease of the system and making adjustments accordingly. This research will offer libraries an insight into how the community is using the eBook collection. The best way for libraries to improve the services they are offering is to communicate with their patrons and discover what they want and need (Buczynski, 2010). Only through understanding the needs of the public can the library provide them with appropriate services.

This project will also produce findings of interest to New Zealand public libraries and future researchers. Since no research has been undertaken on this topic in this 
context public libraries will be able to discover how patrons are using their collections and whether they are satisfied. This will aid libraries in collection building and customer service delivery. It will also open up the way for future research in this area. This is only a small study but it could easily be replicated and expanded to gain better insight into the wider environment of New Zealand. It could also be repeated in the future to see how usage and opinions have changed over time.

\subsection{Research Questions}

For this research project three main questions, each with several sub-questions, have been devised. These questions will provide an in-depth overview of the situation as a whole. The main focus of the research is around the borrowing process for eBooks and the following questions are designed to reflect this.

- How are public library patrons in New Zealand using eBooks?

- Do patrons use eBooks alongside, or as a replacement for, print books?

- What determines whether patrons select a print or electronic version of a particular title?

- If patrons do not use eBooks, then why not?

- Are patrons satisfied with the eBook borrowing process at their local public library?

- How easy is borrowing an eBook compared to a print book?

- Does only being able to borrow eBooks from home dissuade people from using the eBook borrowing service?

- What improvements, if any, could be made to the current eBook borrowing process?

This final question will allow participants to offer suggestions for the future which can then be added to the discussion and presented as options for the future. 


\section{Literature Review}

\subsection{Introduction}

In 2011 over half of the public libraries in the United States of America reported an increase in the number of requests received for eBooks, compared to previous years (Miller, 2011). Since then the number of public libraries offering eBooks to their patrons has increased, with this increase predicted to continue (Zickuhr et al, 2012). In New Zealand over $92 \%$ of local authority libraries currently offer eBooks, an increase of $87 \%$ in the last two years (LIANZA, 2013). However, not all public libraries are ready or willing to offer such services (Zickuhr et al, 2012). Issues surrounding pricing and the policies of publishing companies have caused some libraries to delay establishing a collection. While some of these issues are out of the direct control of the libraries they can still voice their opinion in the hopes of resolving these problems. The Chartered Institute of Library and Information Professionals (CILIP), and others, have chosen to voice their opinions on publishing issues affecting libraries in the hopes of bringing them to the forefront and developing a solution (see: CILIP, 2012b). Kelly Lynch (2012) suggests that libraries approach publishers and make their needs and concerns known. In order for libraries to keep up to date with new technologies, and the needs of their communities they need to understand what the patrons need; and to work out the problems currently surrounding digital collections. If they fail to adapt to new technologies libraries risk becoming obsolete.

\subsection{Publishing Problems}

There is still much debate as to whether publishers should allow public libraries to purchase eBooks for lending; most of the major publishing companies do not allow it (Harris, 2013). Random House implies that libraries own the titles of the eBooks purchased from them, but all the limitations and restrictions listed in the fine print of sales agreements negate this implication (Harris, 2013). In 2012 several publishing companies raised the prices of eBooks for libraries; Christopher Harris (2013) suggests that libraries would be better to put their efforts into finding another option than trying to own eBooks outright. One of the other options currently available is to lease eBooks to libraries through publishers directly, through vendors, or through 
aggregates (CILIP, 2012c). While negotiations in the USA have allowed libraries to enter into agreements with the big six publishers these agreements are yet to reach other places around the world, meaning content outside of the USA is limited (LIANZA, 2013).

The main issues for publishers surround piracy and the potential fall in eBook sales; this is an unfounded fear as studies have shown that library users are more likely to purchase books than non-library users (Miller, 2011). There are also claims by some companies that piracy will become rampant if eBooks are allowed to be loaned by public libraries (CILIP, 2012a). These issues affect both libraries and publishers and ultimately what the publishers decide will help determine what libraries can lend to users.

Research has found that cost issues have prevented public libraries from offering eBooks to their users (Zickuhr, 2012). When asked if they intended to implement an eBook catalogue in the next two years a number of the libraries surveyed responded that they would not. This issue has been worsened by the recent raising of prices by some of the larger publishing companies (Harris, 2013). There are libraries that are waiting for the problems to work themselves out and for some kind of standard to be implemented. Kelly Lynch (2012) claims this is a bad idea; libraries have huge buying power and so should be proactive and make their concerns and needs known to publishing companies to help resolve the situation. This attitude and demand for a better model has encouraged Bibliotheca to develop an open sourced eBook model. The project has yet to be completed but it aims to help create an integrated future for both libraries and publishers (Polanka, 2012). The intent is to help lower the cost of eBooks for libraries by creating a library cooperative buying platform which will allow negotiation with publishers; and expand the volume of content available to libraries.

\subsection{Borrowing Issues}

Studies have found that while more people are borrowing eBooks, there are continuing issues which prevent people using digital collections to their full potential (Poulson, 2012). EBooks require additional technology and knowledge in order to be used. People who do not have the knowledge required to download an eBook are more likely to continue using print books, unless they are either given the skills 
required or borrowing eBooks becomes as easy as borrowing print books (van der Velde \& Ernst, 2009). There are four main issues that have been identified by library users in relation to borrowing eBooks: ease of access, waiting lists, compatibility and unavailable titles (Harris, 2013).

\subsubsection{Print vs. EBook}

Issues with publishing companies are not the only reason libraries are holding back on establishing an eBook collection. Print is still the most popular book format borrowed at public libraries. Gray and Copeland (2012) found that in 2012 print copies of the ten most popular books circulated four times more than their eBook versions. The same was found by Duncan in Australia (2011); both of his studies found that print was the more popular option despite a greater number of eBooks becoming available.

A number of surveys have been conducted since 2009 examining how individuals in the United States gain access to eBooks and printed books (Ashcroft, 2011; Kumbhar, 2012). The most recent of these surveys found that eBook lending in public libraries had yet to see significant uptake (David Rapp, 2011). This may have changed in the two years since the last survey was conducted. A longitudinal study conducted in Australia found that the use of eBooks increased dramatically over the period between the two surveys and there is no reason to suggest that eBook use would drop in the future (Duncan, 2011). Individual libraries have reported that more people are using eBook collections and own eReaders. Of those who did not have eBook collections, more stated that they were considering using eBooks in the future (Moyer and Thiele, 2011; Duncan, 2011).

Similar results have been found in academic libraries. In one study (McLure et al, 2012) the use of eBooks was on par with print books, but survey respondents preferred to use print books. While eBooks were considered superior for reading short articles or book chapters for research, their shortcomings caused frustration and made print the more popular format for reading books to cover to cover. The shortcomings mentioned were: printing and downloading problems; the incompatibility of some devices with the available formats; and the difficulty some people have reading on the available devices (McLure et al, 2012). 
OCLC has recently completed a number of surveys examining how librarians believe the use of libraries will change over the next five years. A large majority of librarians in each of the countries surveyed believe that online use of the library will increase over the next five years (OCLC, 2012a; 2012b; 2012c). The main reason people use the library is currently reported to be to gain access/borrow books/materials. This is expected to change everywhere surveyed except the Netherlands, where it is believed that this will continue to be the main reason people use public libraries (OCLC, 2012b). Access to online resources is anticipated to surpass borrowing materials as the primary reason people access libraries in Germany and the UK; in the Netherlands this is expected to be the secondary reason people use the library (OCLC, 2012a; 2012b; 2012c). In all three nations econtent and digital initiatives were reported as the most important new initiatives currently underway. The use of eBooks and online content is expected to rise, but the use of print media is not expected to suffer greatly from this and is considered to remain a vital part of a library's offerings (OCLC, 2012a; 2012b; 2012c).

\subsubsection{Technology Issues}

There are a number of platforms on which eBooks can be read, the popularity and efficacy of these varies. Richardson and Mahmood (2011) examined the most popular eReaders of 2011 to ascertain user satisfaction and usability. Dedicated eReaders, notably the Amazon Kindle, are the most popular choice. This is due to eye strain issues with reading for long periods from the screen of non-dedicated platforms. The portability of eReaders is one of the main reasons people choose to purchase them; however, users reported poor navigation abilities on all eReaders surveyed, and disliked the fact that they did not own the books they downloaded. Many respondents were also concerned with the future of their eReaders, they disliked the prospect of having to purchase a new one when theirs became obsolete or stopped working (Richardson and Mahmood, 2011).

The question of compatibility is coupled with publishing problems (Poulson, 2012). Different eReaders use different formats and not all formats are compatible with all devices. This produces problems for libraries when deciding which format to purchase eBooks in. There are a number of formats available but not all books are 
available in all formats (Overdrive. n.d). In New Zealand there are no eBook providers which offer eBooks compatible with Amazon Kindles to libraries (LIANZA, 2013) Users may wish to borrow digital books from their local library but are unable to because their device is incompatible with the library's holdings (Overdrive. n.d). There are also some services where eBooks cannot be directly downloaded to eReader devices and must first be downloaded to a computer then placed on an eReading device (Overdrive. n.d). As a result even more hardware and software is required to download an eBook and the process cannot be done away from a computer.

The technology required to read eBooks is becoming more affordable and is one of the major factors in the rising popularity of eBooks (Duncan, 2011). However there are people who do not have the skills required to operate this technology and so continue to borrow print books. Libraries that have offered classes instructing people on how to use eReaders and how to download a book from the catalogue have had great success. In some cases the demand for classes has continued and even risen (Kelsey, 2012).

Research has found that people would be more likely to borrow eBooks if they came preloaded onto an eReading device. There are number of reasons for this: it would allow customers the convenience and benefits associated with eBooks, while avoiding the difficulties of the borrowing process (Poulson, 2012). Technical barriers have been reported as major contributors to the hesitation of patrons to use eBook collections (LIANZA, 2013). Offering preloaded devices would also allow individuals who are not in the financial position to purchase eReaders to still borrow eBooks (Poulson, 2012).

\subsubsection{Waiting List Worries}

In the information age people expect to be able to access digital information the instant they want it (Zickuhr, 2012). Libraries are no exception to this expectation. One of the differences between print and digital books is that to get an eBook a customer does not have to physically visit the library. This implies that eBooks are easier for people to access but waiting lists remove this perception (Harris, 2013). Waiting lists are a problem because libraries only have limited copies of titles 
available. This is partly because eBooks are still more expensive for the library than print books. EBooks are mostly leased whereas print books are purchased (Gray and Copeland, 2012). Eric Hellman (2012) claims that one of the biggest challenges regarding eBooks in public libraries is "learning how to work alongside publishers and distribution channels to make it as easy for patrons to use eBooks as it is for them to use print books today". However, in the information age users expect eBooks to be easier to obtain than print books, which is currently not the case (Harris 2013). Waiting lists exist for print books as well as eBooks but it seems less acceptable for users to be placed on waiting lists for digital data. Studies have been conducted to discover the options individual libraries have to deal with these issues and help improve patron experience with eBooks, and thus increase the numbers being borrowed (Kelsey, 2012; Sendze, 2012).

Currently the number of eBook titles available to borrow is limited. EBook collections are much newer than print collections and have not had the chance to grow and develop. Not all books are available in digital format; many older books have yet to be digitised, though this is changing thanks to Project Guttenberg and Google (Project Gutenberg n.d; Google Books n.d). There are two main ways for a library to set up an eBook collection: to become a member of a consortium or to purchase them individually (Gray and Copeland, 2012). There are advantages and disadvantages to each, in New Zealand most of the libraries are members of consortiums (LIANZA, 2013). Studies show that a greater number of eBooks were borrowed from libraries where the library individually chose and purchased eBooks (Gray and Copeland, 2012). This method allows libraries to tailor their collection to the needs and wants of their community. The downside to this is that it is more expensive than becoming a member of a consortium and limits the number of available titles. Developments are being made in an attempt to try and combat this. Bibliotheca has responded to frustrations expressed by librarians regarding the eBook purchasing and borrowing experience (Polanka, 2012). Their current plans are to create an open source eBook model which will be integrated seamlessly with all major Integrated Library Systems (ILS) in the hopes of creating a more user friendly environment for patrons, while providing benefits for libraries themselves (Kelley, 2012). 


\subsection{The Librarian's Perspective}

A large proportion of the literature on eBooks is focussed on librarians and the libraries themselves, often academic libraries (Ashcroft, 2011). Research on the needs and opinions of users has been discussed here, however most current research in public libraries is centred on the libraries; their staff and their responses to eBook implementation. Libraries have had to adapt to eBooks as traditional ways of acquiring, cataloguing and storing do not necessarily work. This means new systems are a work in progress (Ashcroft, 2011).

In order for eBook collections to be fully utilised libraries need to spread word to their patrons about what they have available. Librarians also need to be trained in the using of the eBook collection so that once customers become aware of the collection there are staff members who are able to help patrons who are having difficulties (LIANZA, 2013). Marketing eBook collections has not always been done effectively; many people are unaware that they have access to an eBook collection through their local library until they enquire about it (Buczynski, 2010). EBooks can be more difficult to publicise as unlike print books they cannot be displayed in the library. Libraries are finding new ways around this, such as signs displayed in the library. There is no right or wrong way to publicise eBook collections; successful methods will depend on the individual libraries (Buczynski, 2010).

The promotion of eBook collections is reflected in recent research along with different methods libraries have used to address issues surrounding the addition of eBooks. One experiment aimed to improve services by adapting techniques they have for print books, such as special displays and easy browsing, to eBooks (Sendze, 2012). While the use of eBooks dramatically increased between 2010 and 2011 the library services were lagging behind. The library was not providing easy and efficient service which resulted in confusion and frustration for the patrons who wanted to borrow eBooks (Sendze, 2012).

Difficulties with eBook implementation have not gone unnoticed, the calls from librarians for an easier to use system have been responded to in a number of ways. Bibliotheca are currently working on a new system of purchasing and offering 
eBooks to bring down prices and make interfaces more user friendly (Polanka, 2012). 3M has created a new Catalogue Acquisition Tool (CAT) to make buying digital content easier for mass buyers, such as libraries (Enis, 2013). The system offers multiple shopping carts, and a design interface which lets users see what they have selected and how many of each item. It also offers genre and 'read like' lists so content managers can easily find items they wish to purchase (Enis, 2013). These new developments show that librarians are being listened to and that the results of recent studies are being taken into consideration when planning for the future.

\subsection{Summary}

There is a gap in knowledge which could be filled by more studies centred on patrons' use of eBooks in public libraries, and the borrowing processes currently in place. This research project has identified this gap and is attempting to begin to fill it by conducting a new study to discover the state of eBook lending in public libraries. Once this knowledge is gained it will be possible to move forward and develop improved methods for lending eBooks, and even for getting them into libraries in the first place. Until the gap in knowledge is filled libraries will be struggling to understand what their patrons want and expect, so further research will help optimise eBook lending. All of the articles reviewed here looked at the issues surrounding eBooks in Public Libraries in different contexts. However they all agreed on one point: there is not enough information about the needs and expectations of patrons. This needs to be addressed if improved services are to be implemented. 


\section{Methodology and Method}

\section{1 Research Design}

This research project has been conducted as a one off study at Christchurch City Public Libraries. This method has been chosen for a number of reasons. The main reason is that it is simply not feasible to perform a nationwide, in depth study in the time provided. It is also not possible to undertake such a large scale study, as the scope of the 580 research project is much smaller than it would need to be for such a project. As Christchurch is a major New Zealand city conducting this research there will mean that a large number of people will be available to participate, yielding a greater response than if a smaller town were selected as the research subject (Leedy \& Ormrod, 2010). The problem with this method is that opinions in Christchurch may not be the same as those in other parts of New Zealand and this research cannot be said to be a representative sample of the country as a whole. There is a gap in the research on this topic both in New Zealand and around the world; a study of this nature will help to begin to fill that gap. It will create a place from which other researchers can go and conduct other research in the same area. There are time and funding constraints which have prevented the research from being conducted as a longitudinal study (Leedy \& Ormrod, 2010). This approach would be beneficial to see how opinions change over time, although as previously stated this study could inform researchers who wish to carry out more in depth and longer studies.

\subsection{Method}

Two different data collection methods were used during this project; one quantitative, one qualitative, they were split into Phase One and Phase Two. Phase One was the collection of data from the library patrons using self-completion questionnaires (Appendix One). A quantitative approach was selected for Phase One as this method was best suited to the research problem; however there was space left on the questionnaire for qualitative comments. The research is looking at the use of eBooks and this is best represented in statistical data (Leedy \& Ormrod, 2010). The questionnaires were designed to take no longer than five minutes to complete in order to cause minimal disruption to the library patrons, while still collecting the required information. I made a continuous circuit around the library stopping to ask 
every third person spotted if they wanted to participate in the study. The only restriction being that they were members of the library, library membership status was ascertained and non-library members were not offered the chance to participate in the study. Participants were informed of the purpose for the study and assured that their questionnaires would be kept confidential. They were assured that the data would be kept secure and then destroyed two years after the research project was completed. The participants were given the option of filling out a questionnaire on paper whilst in the library; or filling it out online via a link on the library's Facebook page. This gave people who were short on time the ability to participate in the study from home when they had the time. By offering the questionnaire online it also allowed a wider demographic of people to participate, and allowed participants to select their preferred method of completion. Of all the people approached only three declined to participate in the research. A link to an online version of the questionnaire (Appendix Two) was posted on the library's Facebook page with a message inviting followers of the page to complete the questionnaire online. The link was posted a second time, ten days after the initial posting.

Phase Two was an interview with two staff members of the library. A qualitative approach was required for Phase Two as the aim was to gain an understanding on how changes were perceived by, and had affected, staff members. The staff members who participated were nominated by their team leaders based on their positions within the library. They were the people who have the most contact with the eBook collection. Prior to conducting the interview both participants were presented with an information sheet (Appendix Three) explaining the purpose of the study and they were assured that the data they provided would be kept confidential and that no identifying comments would be made in the final report. They were also made aware that they were able to pull out of the study within a certain timeframe. A qualitative approach was chosen for this as the data that was sought related to the opinions of the staff members rather than statistical facts (Leedy \& Ormrod, 2010). The interview was conducted with both participants at once; it lasted for thirty minutes and was voice recorded and later transcribed. Both participants were given an information sheet and signed a permission form (Appendix Four) allowing the interview to be conducted and recorded. Both participants were asked the same questions, and to protect their privacy they have been given the codenames 
Participant One and Participant Two. The interview was semi-structured in nature with several questions prepared beforehand (Appendix Five) and additional questions asked during the interview to help facilitate discussion and gain additional information. The interview was a one off occurrence.

\subsection{Assumptions and Limitations}

This research was subject to a number of limitations. The questionnaire was only offered to individuals at two of the library service's branches. This was due to the infeasibility of incorporating every branch in the study. Time limitations made it impossible to collect and process data from all twenty available branches of the library, so two of the largest branches were selected as the physical locations for the research to be conducted. It was assumed that as these were the largest they received the most visitations and offered the most representative sample of library patrons in the city.

During weekdays the research was conducted in the morning, while at the weekend it was conducted during the afternoon. This was due to time restrictions on the part of the researcher, as such only several hours each day could be spent conducting the research. The days spent at each library branch were alternated so that equal time was spent in each. Conducting the research in this way could bias the research results as it is assumed people visit the library when their schedules allow, by only conducting research on weekday mornings patrons who visit in the afternoons will have been missed.

Offering the questionnaire not only on paper but digitally was intended to minimise bias as the number of patrons made aware of the research expanded. Social media is a useful tool for communicating with the public but there are limitations when using it. Social media is a fast paced medium and online posts on social networks, such as Facebook or Twitter, can soon become buried under newer posts. Additionally the Christchurch City Libraries Facebook page is only available to those members of the community who themselves have a Facebook page. Linking the page to the questionnaire helped expand the scope of the research, but this expansion was limited and could have created a different bias in the results. People need accounts 
and equipment to use social media, by selecting this method of delivery there may be certain groups who were excluded from participation in the research. 


\section{Results}

\subsection{Introduction}

A total of 100 people filled out the questionnaire: $80 \%$ of respondents filled out the questionnaire on paper in the library, it was not recorded which branch of the library participants were approached in. The other $20 \%$ of respondents filled out the online questionnaire. Not all participants answered all questions, or they wrote in additional answers which were not one of the options provided. These answers were not recorded. A statistical analysis has been conducted with this data to ascertain the per cent of respondents who selected the different options. Comments made by respondents in the qualitative sections of the questionnaire will also be used to show reasoning behind the answers provided. These will also be drawn on in the discussion.

The interview has been analysed using thematic analysis to discover the underlying themes of the data and how they relate to the data gathered from the questionnaires and the main research questions (Guest, 2012).

\subsection{Questionnaire Results}

\subsubsection{Use of Library}

Participants were asked how often they borrowed items from the library, 'items' include print books, eBooks, audiobooks, DVDs and CDs. The most common response was 'weekly' with $36 \%$ of respondents reporting that they borrow items from the library on a weekly basis; $36 \%$ of those who filled out the paper questionnaire and $35 \%$ of online participants borrowed items weekly.

A higher percentage of people who filled out the questionnaire online chose the 'six monthly' and 'less often' options; $30 \%$ compared to $9 \%$ of the paper questionnaire respondents. 


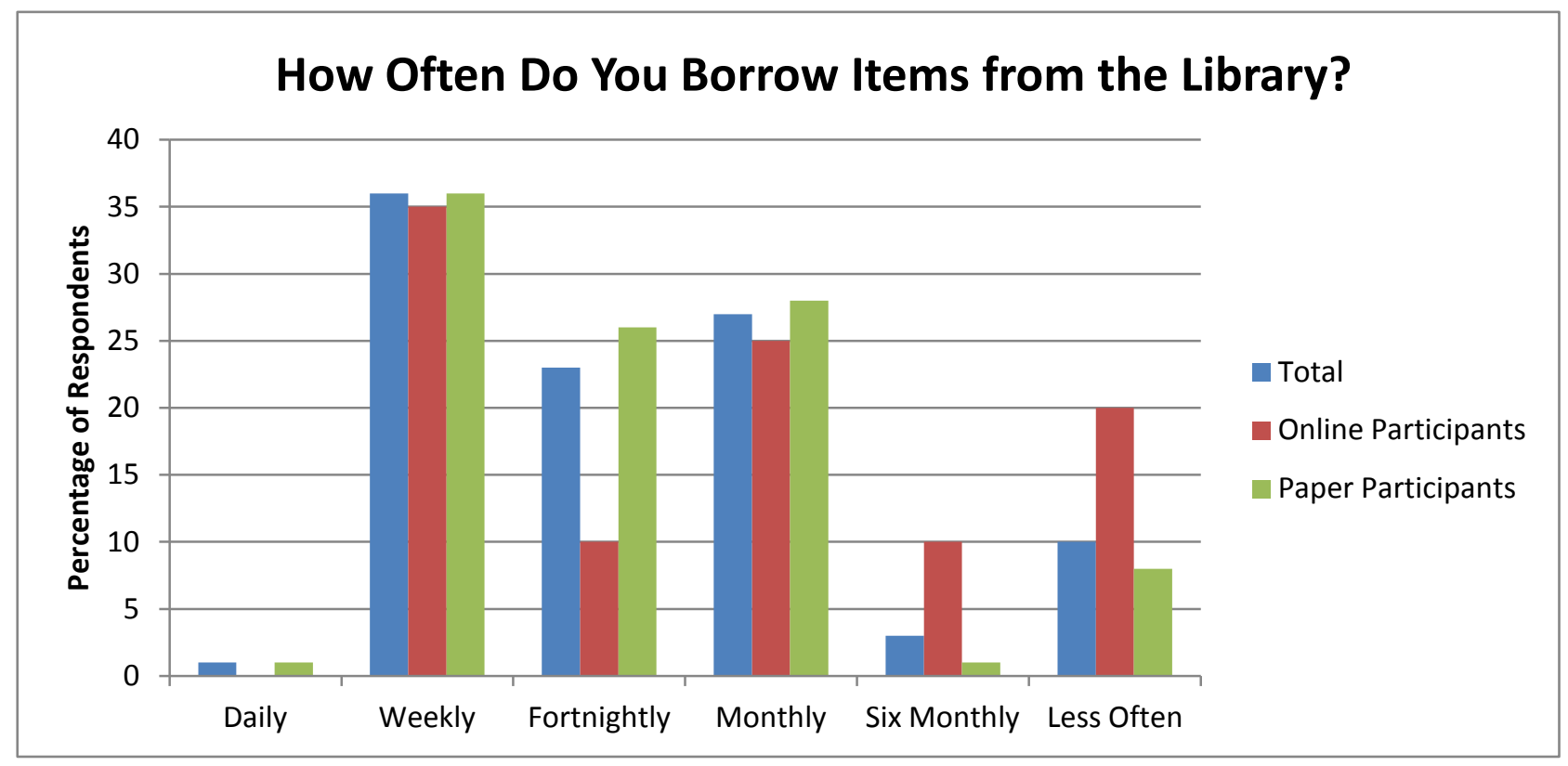

\subsubsection{Format Preferences}

The questionnaire asked whether participants had a favourite format of book when borrowing from the library, $70 \%$ of participants favoured print books. A total of $76 \%$ of participants who completed the paper questionnaire selected print as their favourite format, compared to $45 \%$ of those who completed the online questionnaire. Only $2 \%$ of respondents selected eBooks as their favourite book format; $24 \%$ of participants did not have a preference. The results show that print books are the most borrowed format with $93 \%$ of people reporting they borrow more print than any other format, the other $7 \%$ were unsure what they borrowed more of. When asked if eBooks had replaced print books as their main reading format $94 \%$ of participants said no they had not. No participants reported borrowing more eBooks than other formats. Reasons given for preference of print books include:

- There is a wider selection of print books (4 respondents)

- "The [eBook] collection is tiny".

- They are easier on the eyes (5 respondents)

- "It [print books] feels better for your eyes"; "I don't really like reading on backlit devices so I don't use the library e-book borrowing service often".

- The 'feel' of a print book is better than an eBook (17 respondents) 
- "Nice to hold, and the 'smell' is comforting".

- It [print books] is generally easier on the eyes (I use a tablet not an ebook reader and it is harsher)".

Figure 2, Participants' preferred book formats to borrow from the library

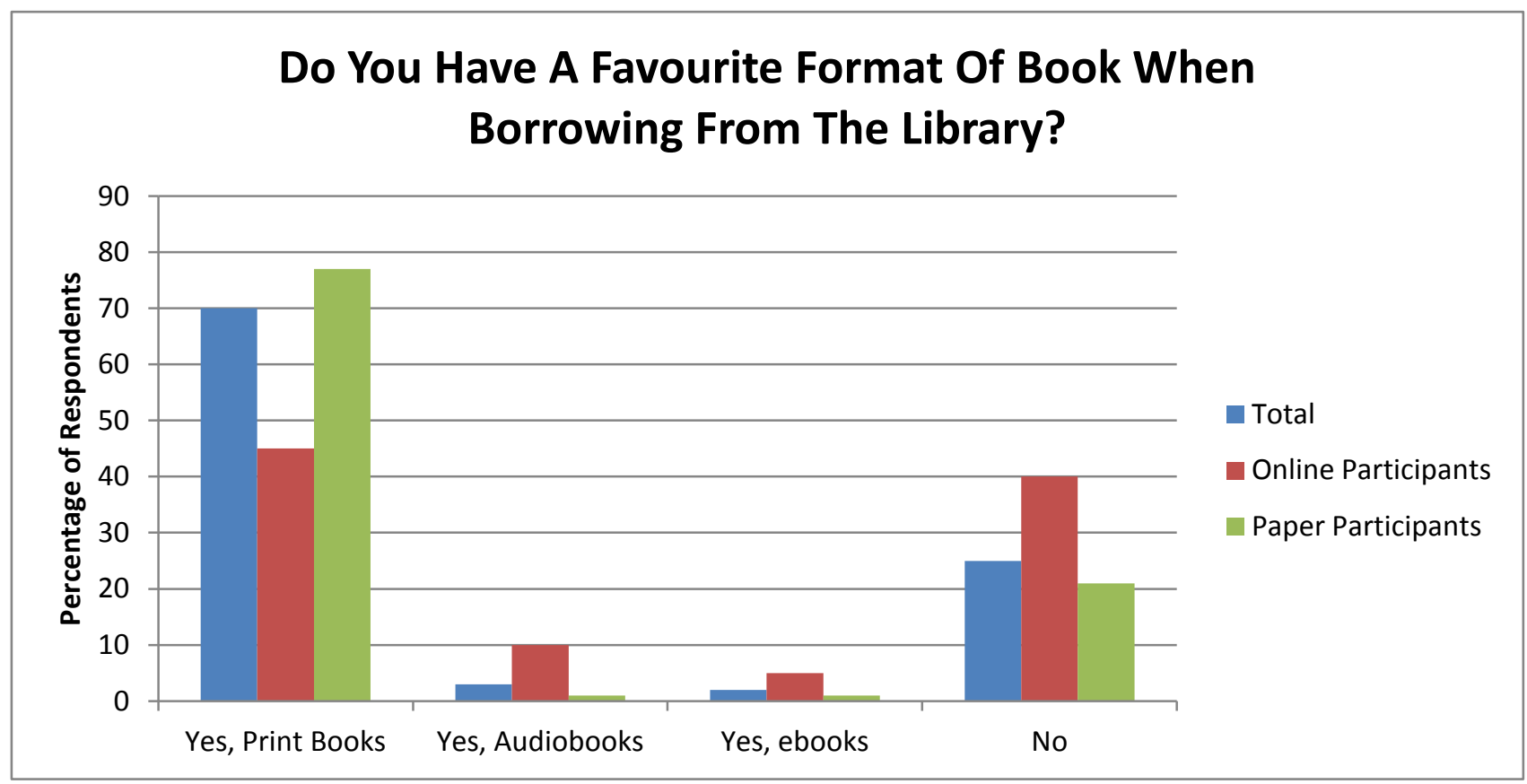

Figure 3, Most borrowed formats

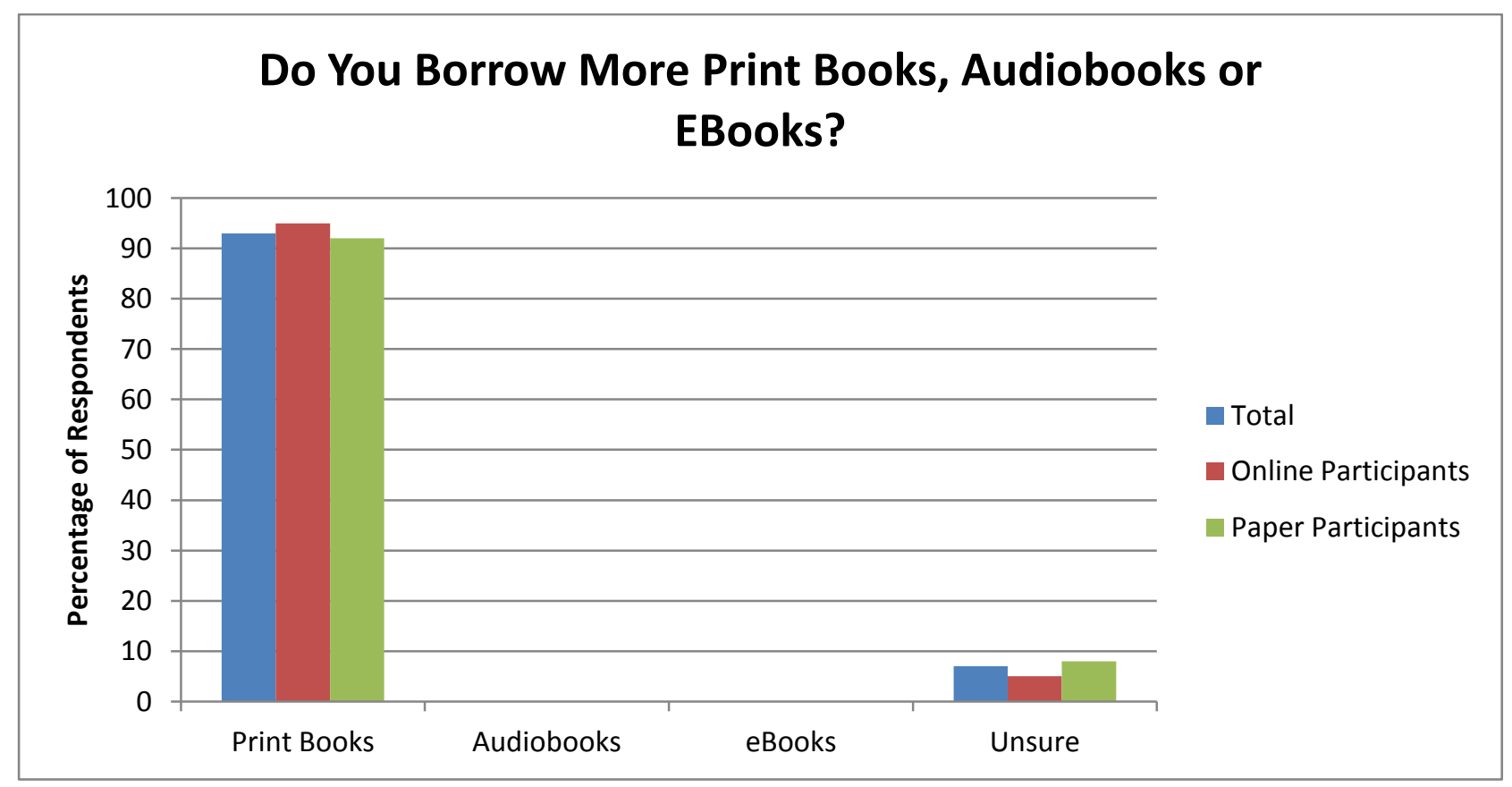




\subsubsection{Use of eBook Collection}

Respondents were asked if they were aware that Christchurch City Libraries had an eBook collection. Over half (64\%) the respondents of the paper questionnaire were aware of the eBook collection compared to $90 \%$ of the online respondents.

Figure 4, Awareness of eBook collection

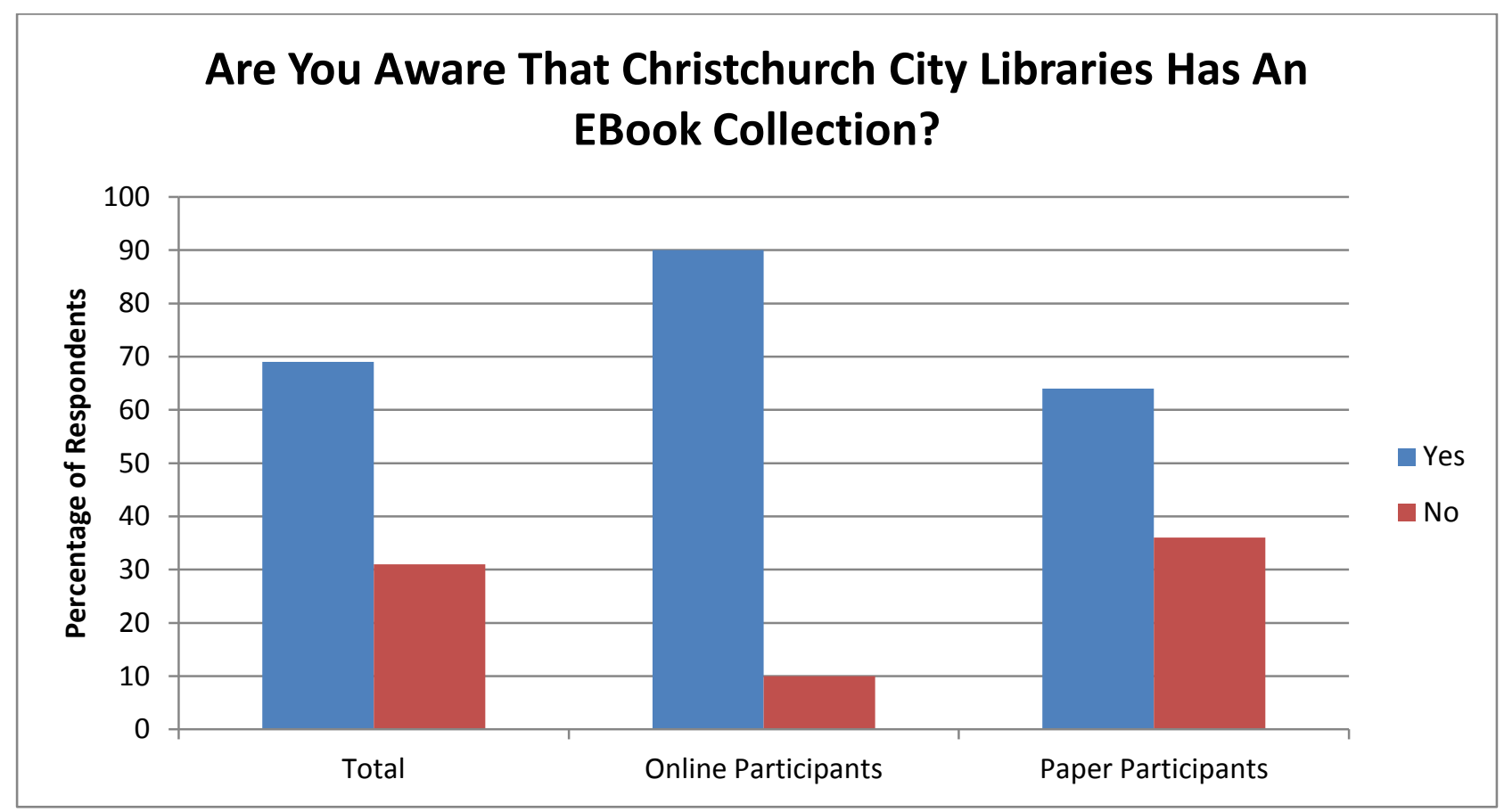

Of the people who were aware of the eBook collection only $39 \%$ had actually borrowed an eBook from the library. Of these participants $63 \%$ filled out the online questionnaire and $37 \%$ filled out the paper questionnaire. 


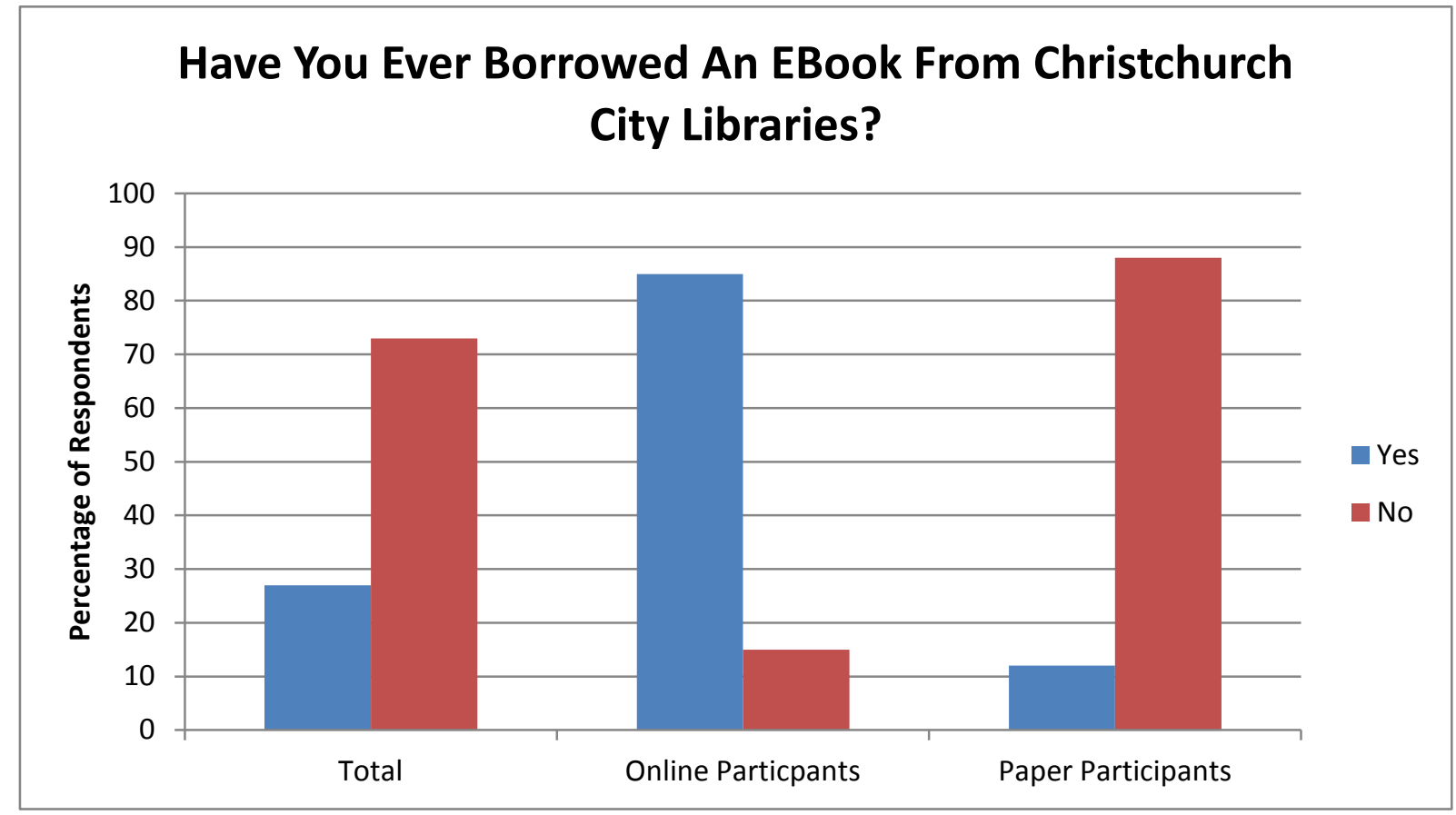

Only $13 \%$ of the respondents had borrowed an eBook from somewhere other than Christchurch City Libraries; 54\% of those who had borrowed an eBook from somewhere else filled out the paper questionnaire and $46 \%$ filled out the online questionnaire. Altogether $30 \%$ of participants had purchased an eBook. More people had purchased an eBook than had borrowed one from Christchurch City Libraries, "if I buy books, 99\% of them are from Amazon, for my Kindle".

Figure 6, EBook borrowing and purchasing statistics

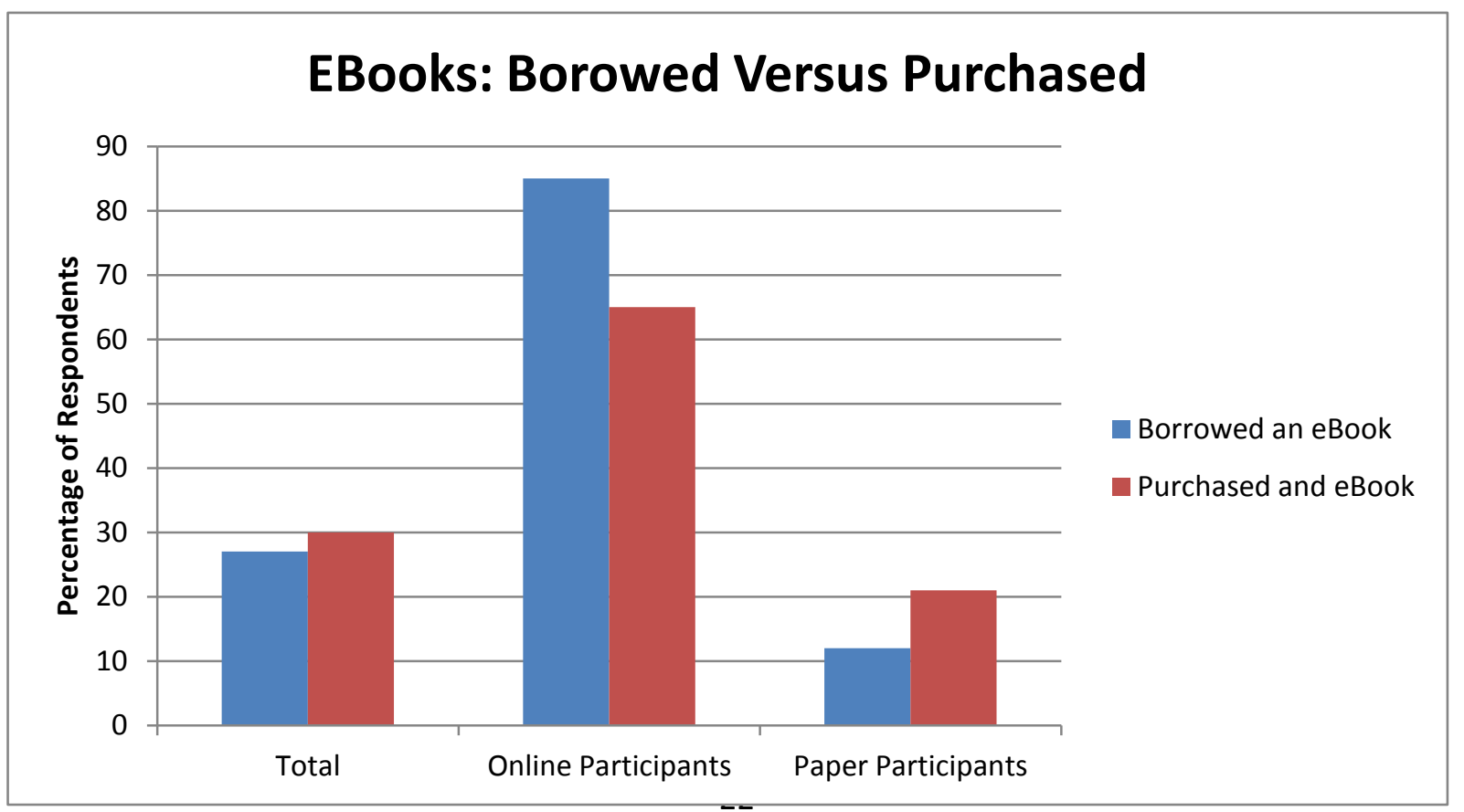


A majority (73\%) of people had never borrowed an eBook from the library, of those $56 \%$ said the reason why they had not was because they did not own an eReader.

Table 1, Reasons for not borrowing eBooks

\begin{tabular}{|l|c|c|}
\hline \multicolumn{2}{|c|}{ Reasons Provided For Not Borrowing An EBook } \\
\hline $\begin{array}{l}\text { I don't own an } \\
\text { eReader }\end{array}$ & 43 & 56 \\
\hline Incompatibility issues & 4 & 5 \\
\hline $\begin{array}{l}\text { I didn't know they } \\
\text { were available }\end{array}$ & 11 & 14 \\
\hline I don't know how & 14 & 18 \\
\hline Other & 5 & 7 \\
\hline
\end{tabular}

\subsubsection{EBook Collection Usability}

Participants were asked whether they felt the current eBook collection met their needs, $62 \%$ answered that it was not applicable to them as they had not used the collection. Of those who had used the eBook collection $57 \%$ of respondents said it did not meet their needs as a user, $21 \%$ of the total responses for that question. One of the reasons given for this was the lack of Australasian content, "Not many books by New Zealand/Australian authors"; "More Kiwi \& Aus. authors would be good". A total of $80 \%$ of online and $40 \%$ of paper questionnaire respondents said they would borrow more books if there were a wider selection. Participants commented that they wanted not only more content but more copies of titles already in the collection "there is limit for the number of people who can 'borrow' the book. So there is a waiting time which I don't understand"; "[there should be] more copies of existing eBooks available - hello it's electronic I don't want to wait to take out an eBook". Just over half $(51 \%)$ of the total participants stated they would not borrow more eBooks if the collection had a wider selection.

When asked if they found the borrowing process simple to complete $78 \%$ of those who had borrowed an eBook felt the borrowing process was simple, this was $21 \%$ of 
the total number of respondents, "I think the borrowing process is already very simple. I asked a librarian to show me what to do the first time, and his explanation was very straightforward, as was the pamphlet he gave me to take home". However there were people who felt that setting up the required software was difficult, "setting up can be difficult - but that's not the library's fault, I don't think. It's just all the technology that needs to be set up".

Figure 7, Potential borrowing with expanded collection

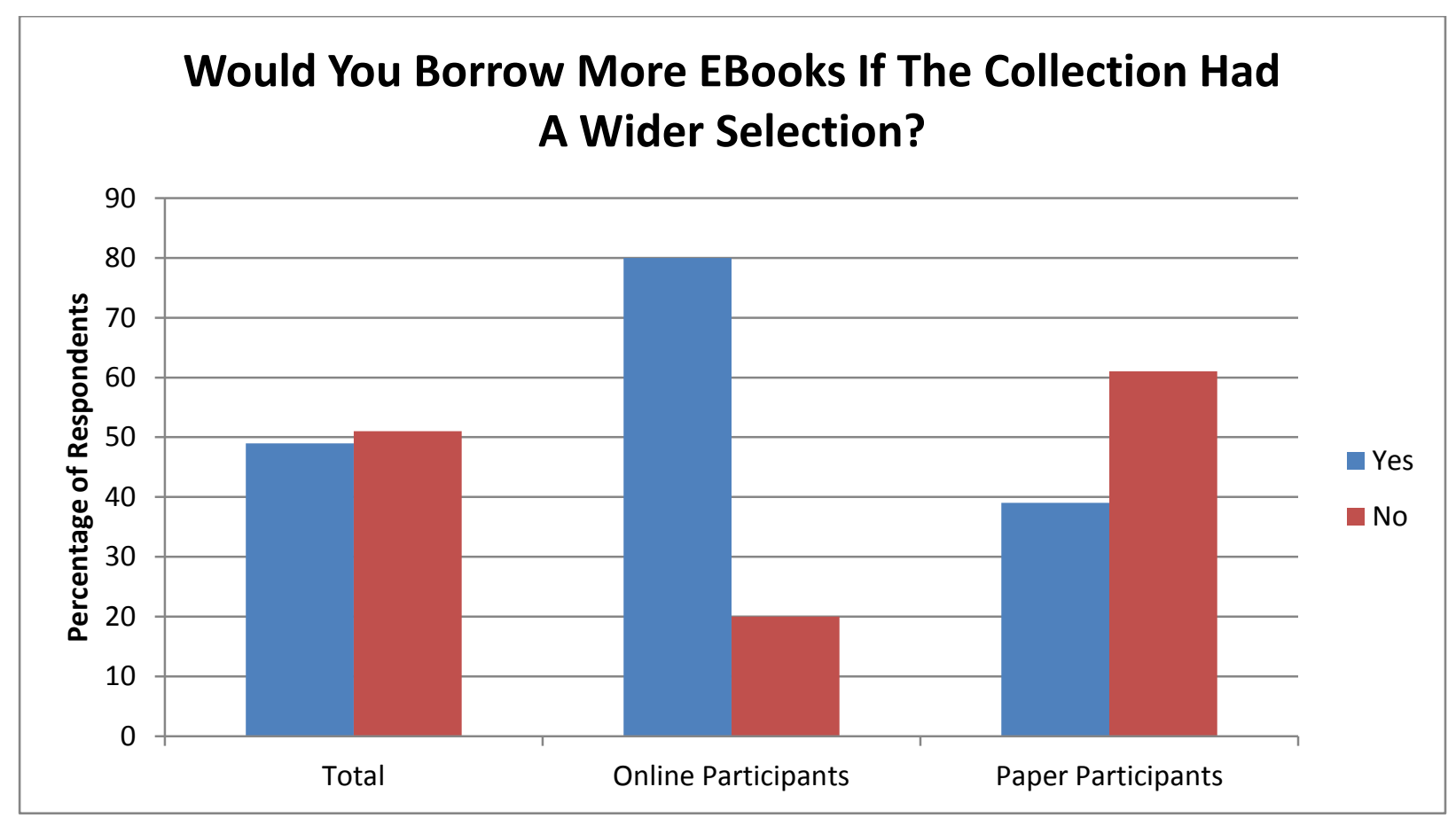

The majority (88\%) of participants were not dissuaded from borrowing eBooks by the fact that they could only do so remotely, and only $33 \%$ of respondents said they would borrow more eBooks if they could do so using the library's computers. 
Table 2, Responses relating to eBook borrowing locations and effect on borrowing habits

Does only being able to borrow eBooks remotely dissuade you from borrowing them?

\begin{tabular}{|l|r|r|r|}
\hline & Total \% & Online Respondents \% & Paper Respondents \% \\
\hline Yes & 12 & 10 & 13 \\
\hline No & 88 & 90 & 87 \\
\hline
\end{tabular}

Would you borrow more eBooks if you could borrow them using the library's computers?

\begin{tabular}{|l|r|r|r|}
\hline & Total \% & Online Respondents \% & Paper Respondents \% \\
\hline Yes & 33 & 15 & 38 \\
\hline No & 67 & 85 & 62 \\
\hline
\end{tabular}

Incompatibility issues were reported by $5 \%$ of the participants as the reason they had never borrowed an eBook from Christchurch City Libraries. In comments seven respondents mentioned Overdrive's incompatibility with Amazon Kindles as preventing them from using the library's eBook service: "it [the eBook collection] does not work on a Kindle so I cannot use it anyway".

\subsection{Interview Results}

Four major themes were discovered in the interview data. Each theme related to one or more of the other themes, along with the main research questions. These themes are defined below and have supporting quotes taken from the interviews. Their relationship with the quantitative data and the research questions will be explored in the discussion section. 


\section{Themes}

\section{Theme One}

Theme Two

Theme Three

Theme Four

\section{Use Of EBook Collection}

Publishing Problems

Frustrations Of A New Format

Borrowing Process

\subsubsection{Theme One: Use Of EBook Collection}

This theme expresses the ways in which customers are using the collection itself; it has both positive and negative responses to the eBook collection based upon trends the library has seen. The positives include the number of customers accessing and using the collection; the negative revolve around the limitations of the current collection. This theme is closely tied with the themes of 'frustrations of a new format' and 'publishing problems' as the collection can only be built with what is available to the library through the publishers. There are difficulties and frustrations in for both the customers and librarians working with a new format.

Christchurch City Library's eBook collection is much smaller than the print collection, with only ten thousand titles compared with over one million print titles. The lack of content has prevented some customers from using the collection as it does not contain the genres they wish to read. That being said there is very little that has not been checked out of the collection, and there are some customers who exclusively borrow eBooks. For some customers privacy is a large reason for borrowing eBooks "One of the things we've noticed is the, what we call, bodice rippers [getting checked out] and it's kind of that whole thing where people can't see what you're reading so it doesn't matter". One of the ways in which the library selects new books to purchase is by examining the most popular titles being checked out. This will lead to a greater amount of certain genres, such as bodice rippers, since they are popular. There are fluctuations in demand for eBooks, for example spikes occur when the library is closed over long weekends. This is interesting as it shows people are more likely to 
use the eBook collection when they do not have access to the print collection. There have also been spikes in usage in January due to people acquiring eReaders at Christmas.

\subsubsection{Theme Two: Publishing Problems}

This theme explores the problems faced by librarians in building an eBook collection with relation to restrictions placed on them by publishing companies. These problems impact on both the librarians and the customers as restrictions limit available titles for purchase. This theme also relates to the themes of 'frustrations of a new format' and 'use of collection' as the limitations and restrictions placed by publishers play a role in creating frustrations, and help shape the collection.

When Overdrive initially showed the library their database of titles, they did not make it clear that there were some titles only available in the USA. One participant said that they were aware of librarians at other libraries having had the same experience, "they [other librarians] didn't realise there was only a limited number [of eBook titles] available". This is an interesting point as it highlights the division in the publishing world between what is available in larger countries, where libraries have more buying power and influence, and smaller countries like New Zealand. This lack of worldwide regulations effects eBook collections at places like Christchurch City Libraries where there are limited titles available for purchase, driving competition for popular titles. Participant One stated that the library has been negotiating contracts with other eBook vendors so they can offer a wider choice to their customers. However this introduces another set of problems, including the marketing of the different vendors to customers:

"If we go through and get another supplier we're likely to then have another window on our [website's] front page, and it's how do you actually entice that customer to go into this one as opposed to that one".

\subsubsection{Theme Three: Frustrations Of A New Format}

This theme relates to the difficulties brought about by starting an eBook collection, and trying to navigate through issues particular to creating a collection of books in a format which is different to anything that has come before. These difficulties are 
experienced by both the librarians and the patrons, though the experiences they have differ due to the nature of their interaction with the eBook collection.

The development of an eBook collection has caused a number of frustrations for the library staff. Both participants agreed that their jobs have had added difficulties since the implementation of the eBook collection in 2011. These frustrations largely centre on problems acquiring eBooks as not all content the library wishes to purchase is available to them. This in turn has led to customer frustrations when seeking particular titles, or finding that titles they want are unavailable due to the limited amount of copies of each title that can be bought by the library, "they [customers] think 'oh well l'll have that' but for a long time that was out". Both participants agree that the library is attempting to change this by looking for multiple suppliers, but this is more challenging than with print books. Print books from different suppliers can be mixed on the shelf and customers will not be aware of where they came from, but each eBook vendor has their own access point online, meaning that the library could end up with multiple small eBook collections with several access points on their website.

\subsubsection{Theme Four: Borrowing Process}

This theme identifies different aspects of the eBook borrowing process and the ways in which the library has attempted to make it as easy as possible. This theme identifies issues which have arisen surrounding the borrowing process and relates closely to the theme of 'frustrations of a new format'; however this theme focuses solely on the borrowing process and includes not only frustrations but the processes put into place by the library. This theme also ties in with the theme 'use of collection' but is separate as it relates to the process of borrowing a book rather than what is being borrowed and when.

The participants agreed that the borrowing process is much simpler now than it was when the collection was first implemented. However, some customers are still having trouble using the system. One participant believed that the initial difficulties with the system have prevented people from using the collection to its fullest "I think perhaps some customers got burned the first time and aren't interested in going [back] because it's deemed too much hassle". Services are available to patrons 
having difficulties, with many customers utilising them, "the fingertip library, our call centre library, a large percentage of what they do now is responding and helping people use the eBooks". It was noted that different learning styles will affect how people approach the eBook borrowing system, some will work through it on their own while others need guidance, and some need to be shown exactly what to do and when. This will relate to the technological ability, and the confidence in that ability, of customers. Those who are highly confident in their abilities will be more likely to work through it on their own, while less confident customers will approach the library for help. It is unlikely that borrowing an eBook will ever be as simple as borrowing a print book.

\subsubsection{Summary}

These four themes are closely interlinked, as the introduction and development of an eBook collection has a number of issues which need to be worked through. While some of these issues, such as collection development and education on operating the collection, can be dealt with by the library there are some issues which cannot. The policies of publishing companies and compatibility problems affect both libraries and their customers, but they are issues the library has little control over. As eBook collections become more developed many of these issues will become less pronounced, though it will take time before any major changes and improvements can be seen. Educating customers will help to eliminate customer frustrations regarding borrowing eBooks, and collection building will begin to give them a wider selection of eBooks to choose from. Not all of the points identified in the analysis are negative; there are already positive benefits of having an eBook collection which will increase as the problems are solved. 


\section{Discussion}

\subsection{Use of Library}

Questionnaire respondents were asked how often they borrowed items from the library, 'items' was not limited to books and included all other media available through Christchurch City Libraries. The most common response was 'weekly' showing that people who chose to participate in this research are active library users. This could bias the data collected as active library users are more likely to know about any services offered by the library, since they are accessing the library's system more often.

A greater number of those who completed the questionnaire online selected the "less often' option, $20 \%$ of respondents; they located the request for research participants through the library's social media sites. Interestingly of those who reported that they borrow items from the library 'less often' the majority commented that they do so because they have Amazon Kindles and are unable to borrow eBooks for their devices. One user commented that they had never borrowed an eBook from the library but would do so if they were available for Kindles. These potential eBook customers, who are already eBook users, are being isolated from the collection. Due to their devices they are unable to use what the library has on offer and it is unreasonable to expect users to purchase a second, compatible, eReader. This results in less people being able to use the collection.

During the interview Participant Two commented that in the library's tracking of Overdrive usage a spike in downloads had been noticed when the library was closed, either during holiday periods or because of the closures that resulted from the 2011 Christchurch Earthquake. This shows that some customers are only using the eBook collection when they do not have access to the print collection, reinforcing the data showing people prefer print books. It was also noted by Participant One that a spike in eBook borrowing occurred in January after the Christmas period, suggesting that people received new devices over Christmas and were taking advantage of the eBook collection on offer at the library. 


\subsection{Use of EBook Collection}

Buczynski (2010) argued that spreading word to library patrons about the existence of eBooks has not always been done effectively. Christchurch City Libraries has chosen a mainly online approach to marketing their collection, as the collection is accessed online through the library's website. This research found that a greater percentage of online respondents were aware of the collection than paper respondents, $90 \%$ of online respondents compared to $64 \%$ of paper respondents. From this we can surmise that online participants were more up to date with the library's digital collections. This is because the eBook collection is accessed and marketed on the library's website and through their social media sites, on which the link to the questionnaire was placed. Over two thirds $(69 \%)$ of the total respondents were aware of the existence of Christchurch City Libraries eBook collection, though much fewer had used it (27\%); meaning that the library is more effective at informing customers of the collection, than enticing people to use it. One respondent suggested that greater education outreach would improve the system as they were currently unaware of how it worked, although they were aware of its existence. The technology barriers faced by customers was identified as a recurring theme throughout New Zealand in the lack of eBook use (LIANZA, 2013), showing it is not only people of Christchurch who have difficulty using eBook collections. Only fourteen of the hundred participants stated that the reason they had never used the eBook collection was that they were unaware of its existence.

A correlation was found between those who had completed the questionnaire online and those who had used the library's eBook collection. Over $80 \%$ of respondents to the online questionnaire had borrowed an eBook from the library compared with $10 \%$ of those who had completed the questionnaire on paper. There are a number of possible reasons for this large difference in usage: respondents who completed the questionnaire online have an active online presence themselves, as they accessed the questionnaire through social media sites, meaning they are more likely to be familiar enough with technology to use the eBook collection. It is also possible that people who use eBooks do not physically visit the library as often as those who do not, and so were less likely to be approached and asked to participate in the research in the library itself. 
The primary reason given by participants for not using the eBook collection was that they did not own an eReader (56\%). Unlike print books, eBooks require additional technology to make them work. It was noted that those who had used the eBook collection on devices such as tablets, computers and smart phones did not use the collection often. This was because they did not enjoy reading on these devices. Dedicated eReaders are the most popular way of viewing eBooks due to specifically designed screens which cause less strain to eyes (Richardson and Mahmood, 2011).

It is possible that the additional technology required to view eBooks prevents people from using the library's eBook collection. The multiple software programs required, and navigation through Overdrive requires a great deal more technical skill than borrowing a print book and is a concern to library patrons (LIANZA, 2013). The lack of knowledge required to use the technology was a response given by several participants as to why they had not used the eBook collection (18\%), this lack of knowledge could be intentional as several respondents made it clear they had no intention of using, or interest in, eBooks. It is also possible that some customers of Christchurch City Libraries do not want, or cannot afford, to purchase a dedicated eReader and so have not used the eBook collection. Poulson (2012) found that people were more likely to borrow eBooks if they were preloaded onto library owned eReaders, this could be explored further at Christchurch City Libraries.

The results of this research show that more people had purchased an eBook than had borrowed one from Christchurch City Libraries, 30\% of participants had purchased an eBook, compared to $27 \%$ who had borrowed one. While this difference is not great it is worth noting that more respondents were willing to go and pay for something they should have been able to access through the library for free. One of the reasons for this difference is incompatibility issues. There is no eBook vendor in New Zealand that offers libraries eBooks which are compatible with Amazon Kindles (LIANZA, 2013). Seven respondents commented that they owned Amazon Kindles which they regularly bought eBooks for, but which are not compatible with the eBooks offered through Overdrive. In the interview Participant One commented that the incompatibility of Amazon Kindles is "another customer frustration because they've been given a Kindle for Christmas and they think' ah I will 
just go to the library' and they can't". Compatibility of eBooks with Amazon Kindle is out of the control of the library and falls under the theme of publishing problems, as identified in the interview data analysis. However, it is important for the library to be aware of this issue and to explore potential ways of negating this problem. These results agree with Harris's (2013) findings that confusion and competition in the publishing world is negatively impacting eBooks in libraries.

\subsection{Format Preferences}

As with Duncan (2011) this research has found that print is still the most popular format being borrowed from the library. The majority (70\%) of respondents identified print as their favourite format to borrow; print is also the most borrowed format (93\%). Several reasons for this were provided, the most common being that the print collection has a wider selection of books. The unavailability of current, popular fiction as eBooks in New Zealand is a preventing customers from using eBook collections (LIANZA, 2013). Christchurch City Library's eBook collection currently has ten thousand titles; this is a very small percentage of their overall collection which currently sits at over one million titles. The eBook collection was begun in 2011 and has not had the time to develop that the print collection has. However the lack of selection and titles is only partly due to the age of the collection, another reason the collection is still small is that it is more difficult for libraries in New Zealand to gain access to eBooks. The interviewees reported that there is less content available through Overdrive in Australasia than other parts of the world. There are also limited licences available for those titles which are released in New Zealand and Australia, resulting in more competition for books, as such it is easy to miss out on popular titles.

Print is still overwhelmingly the most borrowed format at Christchurch City Libraries. It can be seen that $93 \%$ of participants reported borrowing more print books; the other $7 \%$ were unsure which format they borrowed more of. This result supports Rapp's (2011) finding that eBook lending has yet to take off in libraries. Further support for this can be seen in the interview data; when discussing requests made by customers for new books Participant Two stated that "we probably get twenty requests a day [for print books] and we might get two or three a month [for] eBook titles, maybe a wee bit more". The way print books feel was the primary reason 
provided for why respondents prefer print books; they believe the feel of a print book is superior to that of an eBook. Seventeen participants made comments relating to the nature of a print book when asked to explain why it was their favourite format. An eBook does not have the same weight or sensations in the hand that a print book has, one respondent commented that print books were "nice to hold, and the 'smell' is comforting". The data shows that people are happy with the format they are used to, they also see reading as an experience which incorporates all senses and an eBook simply can't provide the same experience.

A second reason participants gave for their preference of print books was that they are easier on the eyes. Richardson and Mahmood (2011) found that people prefer to read eBooks on dedicated eReaders and are more likely to do so if they have access to one. This is because traditional screens can tire the eyes when using for long periods of time. In this research a high percentage of respondents reported not owning an eReader, or having an incompatible reader (61\%). This means that if they have used the collection they have only been able to view eBooks on devices such as tablets and computers. Several participants in this research who had used the eBook collection on other devices noted the strain on their eyes in their questionnaires. These experiences are giving people a negative view of eBooks, which are not harsh on eyes when viewed on an eReader.

\subsection{EBook Collection Usability}

Over half $(57 \%)$ of the questionnaire respondents who had used the eBook collection felt it did not meet their needs as a user. One reason given for this was the lack of Australian and New Zealand material. Library patrons desire a greater amount of local content in the eBook collection, how feasible this is depends on how many publishers are turning new and existing New Zealand and Australian content into eBooks. A second reason was that the collection does not have a wide enough range.

Harris (2013) argued that information age library users expect obtaining eBooks to be easier than print books as they are digital forms of information. This view was also expressed by Participant Two who remarked "our customers expect it to be as easy as a regular book". It is not surprising then that $65 \%$ of online respondents felt 
that the current collection did not meet their needs; as discussed previously online users are more likely to be familiar with attaining digital information due to their online presences. It was noted by several respondents that they did not understand why some eBooks needed to be placed on hold and why there was a limited number of copies for each titles. This misconception could be removed if patrons were offered more education on what eBooks are and how the system actually works. Additionally a more flexible access model would help negate the problem of too few copies, as allowing simultaneous usage of eBooks would help reduce waiting lists (LIANZA, 2013). Waiting lists were identified by Harris (2012) as one of the four main eBook related issues experienced by library users. Waiting lists are a common occurrence with print books but users expect eBooks to always be available, possibly due to their intangible nature.

The majority of online participants (80\%) and over half of the paper participants $(65 \%)$ said they would borrow more eBooks if the library had a larger collection. The current eBook collection is less than one per cent of the total collection held by Christchurch City Libraries. The library has put into place a plan to increase the size of the eBook collection over the next three years, Participant One remarked that they are "looking at increasing the size of our collection by $30 \%$ each year for the next three years". OCLC (2012) found that libraries around the world are prioritising the growth of their digital resources and collections. This is also true of Christchurch City Libraries, they intended to grow their collection so that twenty per cent of their total collection is digital. This will require a great deal of investment into new digital resources, such as eBooks, and education on the operation of these resources.

In 2012 Kelsey (2012) found that classes teaching customers how to use eReaders and eBooks had helped increase the use of eBook collections. Christchurch City Libraries offers some help to customers in using devices and the eBook collection, Participant One remarked that "our fingertip library team manage to be able to talk to customers at the same time as downloading things". When asked if they found the eBook borrowing process simple to complete over seventy per cent of those who had borrowed an eBook answered in the affirmative. One respondent commented that they asked a librarian for help and were taken through the entire process and provided information to take home with them. This shows that the people who are 
aware of the help on offer at the library are using it, though there were a number of respondents who felt that more education on how to use the system would increase their chances of using it. The help on offer needs better marketing to make its existence known to all customers.

It was not the borrowing process itself but the initial setting up of required software which has caused problems for respondents. Before even be able to borrow an eBook patrons must first download, install and set up multiple pieces of software all while agreeing to follow the different terms and conditions of each (LIANZA, 2013). Participants felt that the setting up process required too many steps and should be made to be a one step process. The library has little control over the system Overdrive has in place, therefore the best way for customers to be helped is for them to be made aware that the help service the library offers. Despite the difficulty some respondents had in borrowing eBooks only one third of respondents said they would borrow more books if they could do so using the library's computers. One reason for this is that a number of respondents were not interested in using eBooks at all, preferring print books and so would not use the collection anyway. The majority $(88 \%)$ of participants who were interested in using the collection were not dissuaded from using the eBook collection by only being able to download and transfer eBooks using their own devices. Only $12 \%$ of respondents reported that not being able to complete the borrowing process in the library stopped them from borrowing eBooks. These are likely to be people who feel they need help using the collection but do not, or are unable, to bring their own devices into the library. 


\section{Conclusion}

Research data from around the world has shown an increase in the use of eBooks, how significant this increase is depends on where in the world the research was conducted (Zickuhr et. al, 2012). This research has found that the majority of people surveyed were aware of the existence of Christchurch City Library's eBook collection, though only slightly more than a quarter of people asked had borrowed an eBook from the collection. One of the reasons for this is incompatibility issues; through no fault of the library Amazon Kindles are incompatible with the eBooks they have on offer. This led to an interesting statistic, that more respondents had purchased an eBook than had borrowed one. The library is well aware of the incompatibility issues and from the interview data it is easy to see that it is as much a frustration to them as it is to their customers. There is little that can be done about this currently in New Zealand, though the library has expressed hope that now that Overdrive is compatible with Kindles in the USA (Overdrive. n.d) they will expand that service to their customers around the world.

A lack of eReading devices is the main reason people are not using the eBook collection. Pervious research (Richardson and Mahmood, 2011) has shown that people prefer to read eBooks on dedicated readers and so not having access to one is preventing people from using the collection. Christchurch City Libraries does not currently offer preloaded eReaders to its customers; this approach has been successful elsewhere (Richardson and Mahmood, 2011) though may not be suitable for every library. The reasons why people have not purchased eReaders are not known as this was not asked in the questionnaire, there were a number of participants who stated that they simply preferred print books and so had no intention of spending money on an eReading device.

It has been noted previously (Buczynski, 2010) that there are numerous ways libraries can advertise their eBook collections, though this advertising is not always effective. This research found that over two thirds of respondents were aware of the eBook collection even though not all of them knew what exactly an eBook was. With 
the vast array of resources on offer at the library it may not be possible for every member to be aware of everything but the library's methods have been more effective than others (Buczynski, 2010).

The ease of the borrowing process was a main focus of this research and it was found that the majority of those who had borrowed an eBook found the process easy to complete. A greater number of participants who had completed the paper questionnaire found the process difficult, suggesting that they were less familiar with the technology than those who completed the questionnaire online. A number of comments suggested that the borrowing process could be improved if it were made into a one step process and as simple as borrowing a print book. The library has help on offer for customers having difficulty accessing digital resources. Several respondents had used the services available but an increase in advertising for them may help spread awareness of their existence and change people's perspectives of the eBook borrowing process. As found in previous research these technology help sessions are effective and can be very popular if managed in the right way (Gray and Copeland, 2012).

This research aimed to discover how patrons were using eBooks; it has found that eBooks have not replaced print books for most participants. As found with previous research (Richardson and Mahmood, 2011) print is still the most popular format, partly due to the wider variety of print books available at Christchurch City Libraries. The data also shows that some people are happier using a format they are familiar with. Researchers (van der Velde \& Ernst, 2009) have argued that there will always be a market for print books, a position agreed with by both interview participants. Not only is print favoured by most participants but it is overwhelmingly the most borrowed format. This is largely because of the wider selection of print books and the incompatibility of Amazon Kindles with the library's collection, coupled with the relatively new status of eBooks. A large number of respondents felt that the eBook collection was not large enough and did not contain the genres they wished to read; this has been acknowledged by the library and is something they are working on changing. The library intends to grow their collection so that it holds a greater volume of titles and a wider selection of genres. This should increase use of the 
collection as those who previously did not use it because they found it lacking will have a greater choice and find it more to their liking. 


\section{Recommendations}

From the data collected a number of recommendations have been devised for Christchurch City Libraries to consider in the improvement of their eBook services. These recommendations are:

- To continue to raise customer's awareness of the eBook collection. By increasing awareness the library should be able to increase usage of the eBook collection.

- To entice customers to use the eBook collection by creating displays within the library branches depicting available eBooks, with staff picks and new releases being featured. This will help bring awareness and interest to those customers who lack an online presence and so cannot see the information on the library's website.

- To explore the possibility of offering preloaded eReaders to customers. This has proven a successful way of offering eBooks to customers at other libraries and is worth exploring further, though it may not currently be feasible.

- To continue training staff on the use and operation of eBooks and the eBook collection so they can help customers effectively and efficiently. Staff training in digital technologies is important as customers rely on staff to given them accurate and effective help. This is not something that can be done overnight but is already underway at Christchurch City Libraries.

- To make eReader compatibility information obvious and available in library branches, as well as online. Compatibilities issues are outside of the control of the library, but getting correct and useful information to their customers is a vital part of a library's services. Since not all customers use the website regularly it is important to have information readily available should someone want it.

- To continue to increase the size and variety of the eBook collection. The library already has a plan for putting this recommendation into effect. Customers desire a greater selection and variety of eBooks which will increase usage of the collection. 


\section{Future Research}

This was a small scale research project conducted with a very small sample of the members of Christchurch City Libraries, there are currently over two hundred thousand members of the library and only one hundred were surveyed. As such it may not accurately represent the feelings of the community. However this research offers a starting point for future research on this topic. Research in public libraries on eBook use from a customer perspective is relatively new. Previous research has largely focused either on academic libraries, or eBooks in public libraries from a librarian perspective (Kelsey, 2012). Large scale research on how people use public libraries has been completed overseas (Miller, 2011) and this research project offers future researchers a place from which they could begin such an undertaking in New Zealand. It is also possible for repeats of this research to be conducted in Christchurch in the future to see how attitudes have changed over time. It is not possible to say that this research represents eBook use in New Zealand, as it only covers one city. However it would be possible for this research to be conducted in other towns and cities across the country to gain a more complete picture of eBook use in New Zealand as a whole. 


\section{Bibliography}

An electronic shock: How e-books are transforming the traditional world of publishing. (2012). Strategic Direction, 28(7), 23-28Ashcroft, L. (2011).

Ebooks in libraries: an overview of the current situation. Library Management, 32(6), 398-407.

Buczynski, J. (2010). Library ebooks: Some Can't Find Them, Others Find Them and Don't Know What They Are. Internet Reference services Quarterly, 15(1), 11 19.

Clark, L. (2012). Study: Public Awareness Gap on EBooks in Libraries. American Libraries, 41(7/8), 182-193.

Duncan, R. (2011). EBooks and Beyond: Update on a Survey of Library Users. APLIS, 24(4), 182-193.

. Ebook Acquisition and Lending by Libraries: Public, Academic and Research Libraries. (2012). In CILIP (Ed.): CILIP Policy Department.

. Ebook Lending by Public Libraries. (2012). In CILIP (Ed.): CILIP Policy Department. . Elending in Libraries: Call for Evidence: Submisson from the Chartered Institute of Library and Information Professionals (CILIP). (2012). In CILIP (Ed.): CILIP.

Enis, M. (2013). 3M Revamps Library Ebook Acquisition Tool. Library Journal, 138(9), 21.

Free ebooks- Project Gutenberg. Retrieved October 22, 2013, from http://www.gutenberg.org/

Gibson, C. (2011). An Investigation of EBook Lending in UK Public Libraries. Lecture Notes in Computer Science(6966), 505-510.

Google Books. Retrieved October 22, 2103, from http://books.google.com/ Gray, D., \& Copeland, A. (2012). E-Book versus Print: A Per-Title Cost and Use Comparison of a Public Library's Popular Titles. References \& User Services Quarterly, 51(4), 334-339.

Guest, G. (2012). Introduction To Applied Thematic AnalysisApplied Thematic Analysis: Sage Publications Inc. Retrieved from http://www.sagepub.com/upm-data/44134 1.pdf.

Harris, C. (2013). Ebooks 2013: New leasing models, cheaper devices, more content. Retrieved 20/8/2013, 2013, from 
http://www.thedigitalshift.com/2013/01/ebooks/ebooks-2013-new-leasingmodels-cheaper-devices-more-content-next-big-thing-january-2013/

Hellman, E. (2010). Libraries, ebooks and competition. Library Journal(August), 22. Jr, J. V. R., \& Mahmood, K. (2011). eBook readers: user satisfaction and usability issues. Library Hi Tech, 30(1), 170-185.

Kelley, M. (2012). Integrating Ebooks. Library Journal, 137(7), 46-47.

Kelsey, E. et. al (2012). A Practical, Public-service Approach to eBooks. Public Libraries, 51(1), 42-45.

Kumbhar, R. M. (2012). E-books: review of research and writing during 2010. The Electronic Library, 30(6).

Leedy, P., \& Ormrod, J. (2010). Practical Research: Planning and Design (10th ed.). New York: Pearson.

LIANZA Standing Committee on Digital Content and e-Lending. (2013) E-Book Issues Paper: LIANZA.

Lynch, K. (2012). E-books: the future for publishers and libraries. Collection Building, $31(2), 78-80$.

McLure, M., \& Hoseth, A. (2012). Patron-driven e-book use and users' perceptions: A snapshot. Collection Building, 331(4), 136-147.

Miller, R. (2011). Dramatic Growth. Library Journal(October), 32-34.

Moyer, J. E., \& Thiele, J. (2011). E-books and readers in public libraries: literature review and case study. New Library World, 113(5), 262-269.

OCLC. (2012a). A snapshot of priorities and perspectives: Libraries in Germany: OCLC.

OCLC. (2012b). A snapshot of priorities and perspectives: Libraries in the Netherlands: OCLC.

OCLC. (2012c). A snapshot of priorities and perspectives: UK public libraries: OCLC.

Overdrive n.d Compatibility. Retrieved May 5, 2013, from http://www.overdrive.com/libraries/public-libraries/compatibility/

Polanka, S. (2012). Bibliotheca Spices Up the Library Ebook Market. Online, 36, 5457.

Poulson, D. (2012). How Patrons View Library Ebooks. Information Today(March), 16.

Public libraries expect change, focus on ebooks. (2012). Library Journal, 137(8), 11. 
Rapp, D. (2011). DBW/Verso survey points to ebook lending gap. Library Journal(March), 16.

Sendze, M. (2012). The EBook Experiment. Public Libraries, 51(1), 34-37.

Velde, W. v. d., \& Ernst, O. (2009). The future of eBooks? Will print disappear? An end-user perspective. Library Hi Tech, 27(4), 570-583.

Zickuhr, K., \& et.al. (2012). Libraries, Patrons and E-books. Retrieved 5/9/2012, 2012, from http://libraries.pewinternet.org/2012/06/22/libraries-patrons-and-ebooks/ 


\section{Appendix One: Research Questionnaire Paper Version}

\section{EBOOK RESEARCH QUESTIONNAIRE}

Are you aware that Christchurch City Libraries has an eBook collection?

Yes $\square$ No $\square$

Have you ever borrowed an eBook from Christchurch City Libraries?

Yes $\square$ No $\square$

If 'no' why not?

I don't own an eReader $\square$ Incompatibility issues $\square \quad$ I don't know how $\square$

I didn't know they were available

Other (please state):

Have you ever borrowed an eBook from somewhere other than Christchurch City Libraries?

Yes $\square$ No $\square$

Have you ever purchased an eBook?

Yes $\square$ No $\square$

How often do you borrow items from the library?

Daily $\square \quad$ Weekly $\square \quad$ Fortnightly $\square \quad$ Monthly $\square \quad 6$ Monthly $\square$ Less Often 
Do you feel the current eBook collection meets your needs as a user?

Yes $\square \quad$ No $\square \quad$ Not Applicable

Please explain your answer?

Would you borrow more eBooks if the collection had a wider selection?

Yes $\square \quad$ No $\square$

Do you a have a favourite format of book when borrowing from the library?

Yes, print books

Yes, eBooks

Yes, audiobooks

No

Why do you prefer this one?

Do you borrow more print books, audiobooks or eBooks?

Print books

Audiobooks

$\square \quad$ eBooks

Unsure

Have eBooks replaced print books as your main reading format?

Yes $\square \quad$ No $\square$ 
Do you find the borrowing process for eBooks simple to complete?

Yes $\square \quad$ No $\square \quad$ I have never borrowed an eBook

Does only being able to borrow eBooks remotely dissuade you from borrowing them?

Yes

No

Would you borrow more eBooks if you could borrow them using the library's computers?

Yes

No $\square$

How could the eBook borrowing process be improved?

\section{THANK YOU FOR YOUR PARTICIPATION}




\section{Appendix Two: Research Questionnaire Online Version}
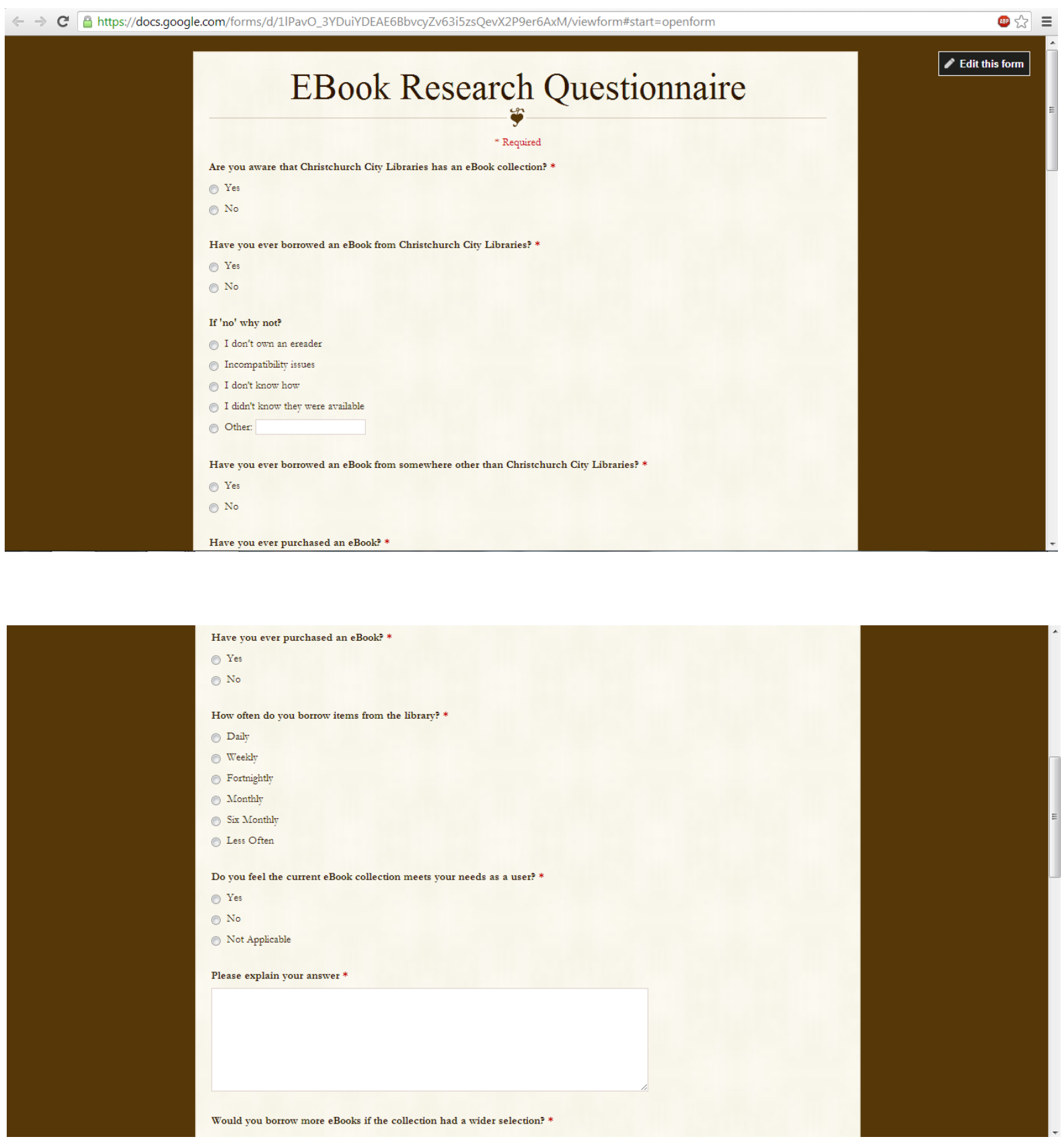
Would you borrow more eBooks if the collection had a wider selection?

Yes

o No

Do you a have a favourite format of book when borrowing from the library?

Y Yes, print books

Yes, eBooks

Y Yes, audiobooks

No

Why do you prefer this one? *

borrow more print books, audiobooks or eBooks? *

(1) Print books

Audiobook

(1) EBooks

(1) Unsure

Have eBooks replaced print books as your main reading format?

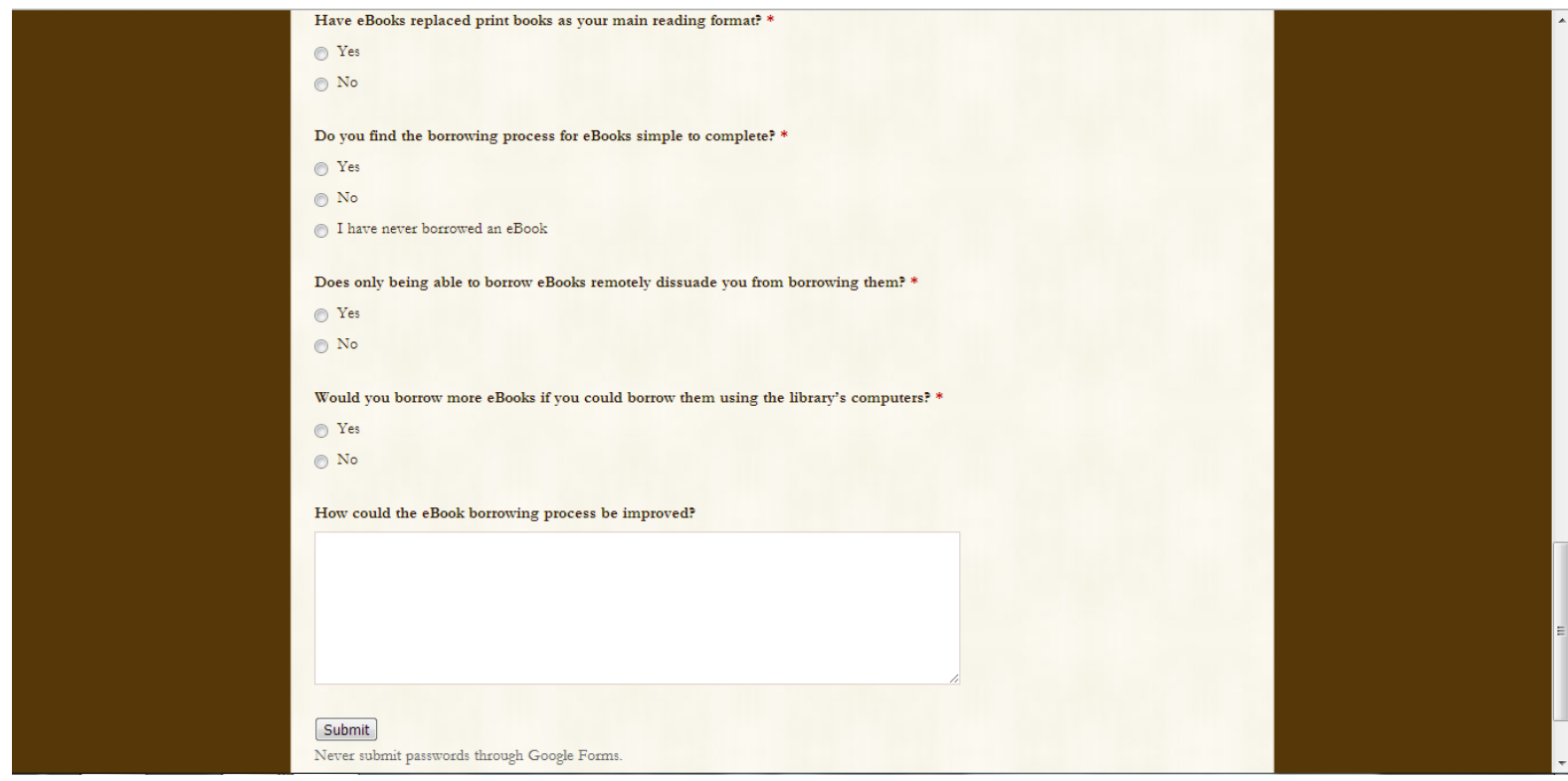




\title{
Appendix Three: Information Sheet For Interview
}

\section{Participant Information Sheet}

\author{
Research Project Title: The Use and Ease of Access of EBooks in Public Libraries \\ Researcher: Nicky Ross, School of Information Management, Victoria University of Wellington
}

As part of the completion of my Master of Information Studies degree this study is designed to discover how people are using eBooks in public libraries. It will also investigate whether patrons are happy with the current procedures for borrowing eBooks from Christchurch City Libraries and how they feel things could be improved. Victoria University requires, and has granted, approval from the School's Human Ethics Committee.

I am inviting members of Christchurch City Libraries to participate in this research. Participants will be asked to fill out a questionnaire, either online or on paper.

Participation is voluntary, and you will not be identified personally in any written report produced as a result of this research, including possible publication in academic conferences and journals. All material collected will be kept confidential, and will be viewed only by myself and my supervisor Prof Anne Goulding, Professor of Library Management. The research report will be submitted for marking to the School of Information Management, and subsequently deposited in the University Library. Should any participant wish to withdraw from the project, they may do so until 18/10/2013 and the data collected up to that point will be destroyed. All data collected from participants will be destroyed within 2 years after the completion of the project.

If you have any questions or would like to receive further information about the project, please contact me at rossnich2@myvuw.ac.nz or telephone 0277742742 , or you may contact my supervisor Prof Anne Goulding, Professor of Library Management at Anne.Goulding@vuw.ac.nz or telephone 463-5887

Nicky Ross 


\section{Appendix Four: Permission Form For Interview}

\section{Participant Consent Form}

Research Project Title: The Use and Ease of Access of EBooks in Public Libraries

Researcher: Nicky Ross, School of Information Management, Victoria University of Wellington

I have been given and have understood an explanation of this research project. I have had an opportunity to ask questions and have them answered to my satisfaction.

I understand that I may withdraw myself (or any information I have provided) from this project, without having to give reasons, by e-mailing rossnich2@myvuw.ac.nz by the 18/10/2013.

I understand that any information I provide will be kept confidential to the researcher and their supervisor, the published results will not use my name, and that no opinions will be attributed to me in any way that will identify me

I understand that the data I provide will not be used for any other purpose or released to others.

I understand that, if this interview is audio recorded, the recording and transcripts of the interviews will be erased within 2 years after the conclusion of the project. Furthermore, I will have an opportunity to check the transcripts of the interview.

Please indicate (by ticking the boxes below) which of the following apply:

I would like to receive a summary of the results of this research when it is completed.

I agree to this interview being audio recorded.

Signed:

Name of participant:

Date: 


\section{Appendix Five: Interview Question Guideline Sheet}

\section{Interview question/prompt sheet}

Tell me about your role here at the library

How have things changed since the introduction of eBooks into the library's collection? (This could include things like budget, changes in catalogue, changes in borrowing habits/online usage etc.)

When did Christchurch City Libraries first implement their eBook collection?

Tell me about the response of customers to eBooks in the library

Has there been a shift in the formats which are being borrowed?

Does it make a difference that Amazon Kindles are not compatible with Overdrive eBooks?

Are you satisfied with the current borrowing process put in place by the library and Overdrive?

Do you think customers find it easy to locate and borrow an eBook?

The eBook borrowing process cannot be completed using library computers; do you think this is preventing people borrowing eBooks?

Do you believe the current eBook borrowing system could be improved in any way?

Where do you see your collection being in five years' time? 